\title{
New tectonic configuration in NE Iran: Active strike-slip faulting between the Kopeh Dagh and Binalud mountains
}

\author{
Esmaeil Shabanian, ${ }^{1,2}$ Olivier Bellier, ${ }^{1}$ Lionel Siame, ${ }^{1}$ Nicolas Arnaud, ${ }^{3}$ \\ Mohammad R. Abbassi, ${ }^{2}$ and Jean-Jacques Cochemé ${ }^{4}$
}

Received 29 December 2008; revised 18 May 2009; accepted 9 June 2009; published 3 September 2009.

[1] In this paper, a combined approach of geomorphic analyses, detailed geological mapping on SPOT 5 satellite images and field surveys, complemented by radiometric dating $\left({ }^{40} \mathrm{Ar} /{ }^{39} \mathrm{Ar}\right)$ allows proposing a new and consistent tectonic configuration for the northeastern Arabia-Eurasia collision zone. It favors a simple strike-slip faulting mechanism in NE Iran accommodating the northward motion of central Iran with respect to Eurasia between the Binalud and Kopeh Dagh mountains. Our results demonstrate that $\sim 2 \mathrm{~mm} / \mathrm{a}(\sim 25 \%)$ of this northward motion has been transferred from the Binalud to the Kopeh Dagh through the Meshkan Transfer Zone since $\sim 5$ Ma. The modern state of stress deduced from fault kinematics analyses shows $\mathrm{N} 30^{\circ} \mathrm{E}$ trending maximum stress axis and confirms a dominant strike-slip faulting mechanism. Combining our geological data with other available data, we conclude that kinematics of deformation can be appropriately described by rigid block faulting in NE Iran; instead, the continuous deformation as it has been thought during the last 3 decades. Citation: Shabanian, E., O. Bellier, L. Siame, N. Arnaud, M. R. Abbassi, and J.-J. Cochemé (2009), New tectonic configuration in NE Iran: Active strike-slip faulting between the Kopeh Dagh and Binalud mountains, Tectonics, 28, TC5002, doi:10.1029/2008TC002444.

\section{Introduction}

[2] At the scale of plate tectonics, the deformation of continental lithosphere seems to be distributed over zones up to a few hundred kilometers wide with the relatively aseismic blocks on both sides. This general character of actively deforming continental domains has led geoscientists to propose two idealized end-member kinematic models. On one hand, it has been suggested that actively deforming

\footnotetext{
${ }^{1}$ CEREGE, UMR, Université Aix-Marseille, IRD, Collège de France, Europôle de l'Arbois, CNRS, Aix-en-Provence, France.

${ }^{2}$ International Institute of Earthquake Engineering and Seismology, Tehran, Iran.

${ }^{3}$ Géosciences Montpellier, UMR 5243, Groupe GEODE, Université de Montpellier 2, CNRS, Montpellier, France.

${ }^{4}$ Laboratoire de Pétrologie Magmatique, Université Aix-Marseille, Faculté des Sciences de St Jérôme, Marseille, France.

Copyright 2009 by the American Geophysical Union. 0278-7407/09/2008TC002444
}

regions are composed of blocks or microplates. Most of the deformation occurs along major block bounding faults, with minor faulting but little internal deformation of the blocks themselves [Avouac and Tapponnier, 1993; Peltzer and Saucier, 1996; Replumaz and Tapponnier, 2003; Ryerson et al., 2006, Thatcher, 2007, and references therein]. On the other hand, deformation is uniformly distributed and continents can be treated as a continuously deforming viscous medium, governed by the fluid-like solid-state flow of a viscous material [England and McKenzie, 1982; Vilotte et al., 1982; McKenzie and Jackson, 1983; England and Molnar, 1997; Flesch et al., 2001]. In this scheme, faults play a minor role and slip in the brittle upper crust occurs on many faults with comparable slip rates. The strengths and limitations of each model have been widely discussed in review papers [Molnar, 1988; England and Jackson, 1989; Gordon and Stein, 1992; Thatcher, 1995, 2003, and references therein]. However, there are perhaps a general agreement that the major unresolved issue is not which of the two extreme models is unconditionally correct, but how the observed deformation can be most usefully and simply described and which intermediate case is most appropriate [e.g., Molnar, 1988; Thatcher, 1995].

[3] Interestingly, NE Iran and specially the Kopeh Dagh (Figure 1) were always referred as a key region to demonstrate the geological reliability of the continuous deformation model [McKenzie and Jackson, 1983, 1986; Jackson and McKenzie, 1984]. According to this model, unstable geometry of strike-slip faults combined with the thrusting, oblique to the boundaries of the deforming zone, will require faults to rotate about a vertical axis until they become parallel to the zone boundary [McKenzie and Jackson, 1983, 1986; Jackson and McKenzie, 1984; Jackson et al., 2002; Hollingsworth et al., 2006, 2008]. However, in the absence of firm quantitative constraints it is difficult to demonstrate the ability of any kinematics model to describe active deformation in NE Iran. In any case, the absence of precise quantitative measures of regional continental deformation has been the chief obstacle in determining which model is able to describe the kinematics of deformation in actively deforming zones [Thatcher, 1995]. Quantitative data, particularly offset amounts and slip rates on major faults hold the key to constrain these models. In this context, the study of the Quaternary faulting yields the most precise average velocities of slip on faults [e.g., Molnar, 1988; Thatcher, 1995; Replumaz and Tapponnier, 2003; Nyst and Thatcher, 2004].

[4] In this paper, we characterize a small but very important region at the northeastern boundary of the 

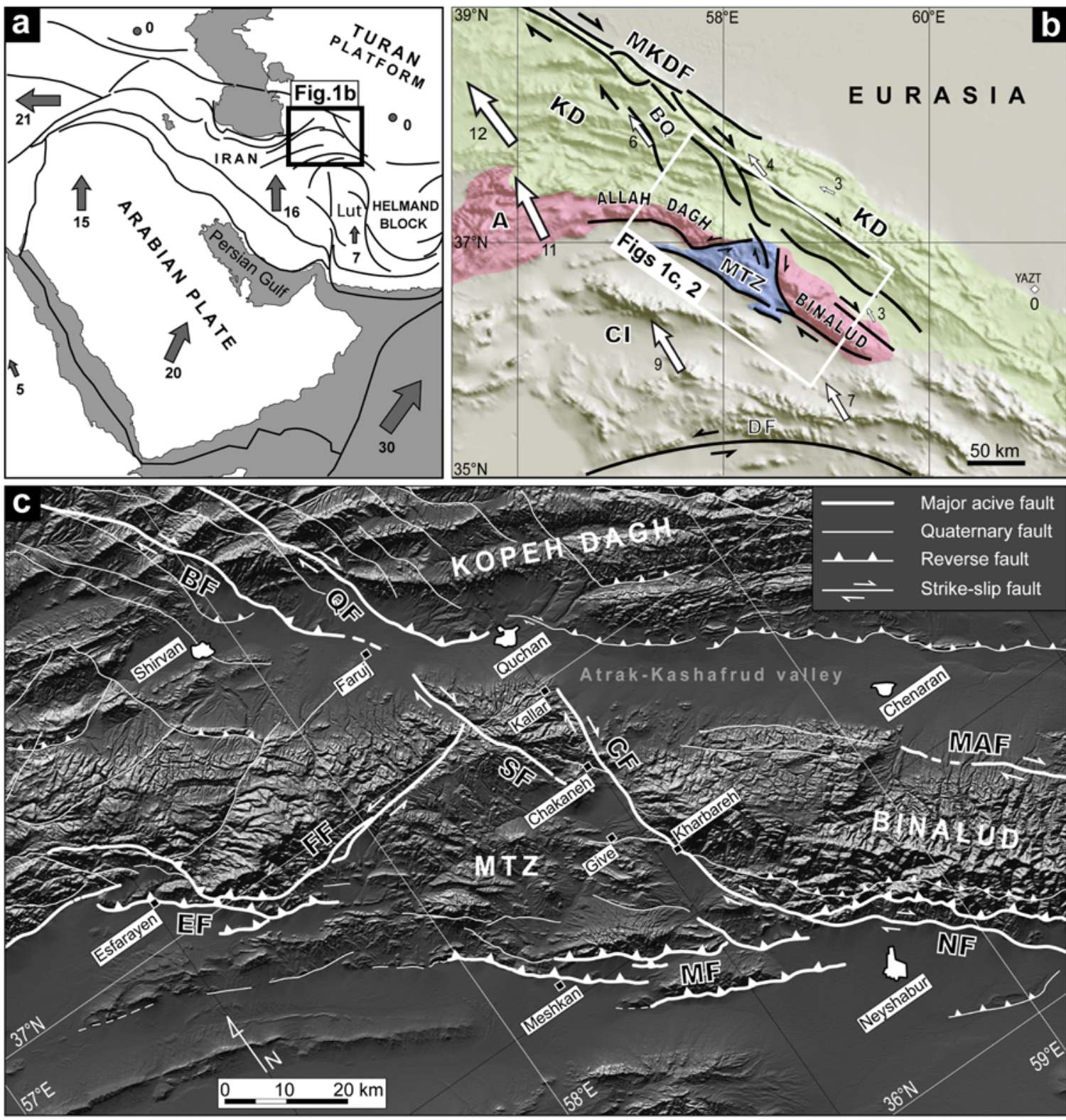

Figure 1. (a) The location of the Meshkan Transfer Zone (MTZ) in the Arabia-Eurasia collision framework. Gray arrows and associated numbers represent Arabia-Eurasia plate velocities (in $\mathrm{mm} / \mathrm{a}$ ) after Reilinger et al. [2006]. (b) GTOPO30 topographic image of northeastern Iran showing the MTZ location in the tectonic context of NE Iran. White arrows and associated numbers are GPS horizontal velocities $(\mathrm{mm} / \mathrm{a})$ in a Eurasia-fixed reference frame (YAZT station [Tavakoli, 2007]). Abbreviations are MKDF, Main Kopeh Dagh Fault; BQ, Bakharden-Quchan Fault system; DF, Doruneh Fault; KD, Kopeh Dagh; A, Alborz; CI, central Iran. (c) Shaded relief image of the MTZ and surroundings (based on SRTM digital topographic data) showing triangular-like fault systems of the MTZ and their structural relationships with the Binalud and Kopeh Dagh fault systems. Fault traces are based on SPOT 5 and Landsat ETM+ image mapping [after Shabanian et al., 2009; this study]. BF, Baghan Fault; CF, Chakaneh Fault system; EF, Esfarayen Fault; FF, Farhadan Fault system; MAF, Mashhad Fault; MF, Meshkan Fault system; NF, Neyshabur Fault system; QF, Quchan Fault; SF, Sar'akhor Fault.

Arabia-Eurasia collision, i.e., the Meshkan Transfer Zone (MTZ), in order to better understand the kinematics of deformation in NE Iran (Figure 1), and respond to a key question: how is transferred the deformation accommodated in the Kopeh Dagh Mountains toward the south? Several approaches of geomorphic analyses, detailed mapping and field surveys, complemented by few radiometric dating $\left({ }^{40} \mathrm{Ar} /{ }^{39} \mathrm{Ar}\right)$ have been used to define and detail the structural and kinematic characteristics of the MTZ. 
[5] The data and results presented in this paper have significant impacts on both kinematic and geodynamic interpretations of strike-slip faulting in oblique convergence domains such as NE Iran. First, our data reveal a new tectonic configuration in which strike-slip faulting oblique to the convergence direction and zone boundary plays the major structural role to take up active deformation in the northeastern boundary of the Arabia-Eurasia collision. This configuration is completely different from what was suggested during the last 30 years. Second, at a more general scale, our data present another possibility for the evolution of a continued convergence; a way in which crustal thickening and growth in area of the range by thrust faulting parallel to the range is not significant. Finally, our data help to better understand the kinematics of deformation in NE Iran and probably in the similar regions submitted to oblique convergence.

[6] After a review of the geological setting and structural framework of the MTZ, the evidences for late Cenozoic strike-slip faulting in the MTZ are presented. Then, we describe morphotectonic and geological investigations conducted along two major strike-slip fault systems, allowing us determining individual Plio-Quaternary fault slip rates. We merge our results with those published by Shabanian et al. [2009] and analyze the combined data set to present a clearer image of the deformation pattern in NE Iran. Then, we compare our model with kinematic descriptions of the Kopeh Dagh deformation proposed in previous studies examining the validity of both rigid blocks and continuous deformation kinematics model for continental deformation at the northeastern boundary of the Arabia-Eurasia collision.

\section{Tectonic Setting and Structural Framework}

[7] Tectonic deformations in Iran result from the ArabiaEurasia convergence. This convergence took place by crustal shortening and strike-slip faulting in different intracontinental deformation domains (mountain ranges) such as the Zagros, Alborz, and Kopeh Dagh mountains. The northward motion of Arabia with respect to Eurasia is accommodated at a rate of $22 \pm 2 \mathrm{~mm} / \mathrm{a}$ at the longitude of Bahrain [Sella et al., 2002; McClusky et al., 2003; Vernant et al., 2004; Reilinger et al., 2006]. According to the available geodetic [Vernant et al., 2004; Reilinger et al., 2006; Masson et al., 2007; Tavakoli, 2007] and geological [Shabanian et al., 2009] data, this northward motion is accommodated in northeast Iran at a rate ranging from 4 to $11 \mathrm{~mm} / \mathrm{a}$. A significant part $(7 \pm 2 \mathrm{~mm} / \mathrm{a})$ of this deformation is localized along the Bakharden-Quchan Fault system (BQFS, Figure 1) within the Kopeh Dagh Mountains [Tavakoli, 2007; Shabanian et al., 2009]. In the Binalud Mountains, the GPS-derived velocity vectors [Masson et al.,
2007; Tavakoli, 2007] indicate 2-4 mm/a of right-lateral strike-slip movement on both sides of the range. Accepting the plate boundary like character of the Bakharden-Quchan Fault system [Shabanian et al., 2009], and the calculated range-parallel GPS rates through the Binalud Mountains [Masson et al., 2007; Tavakoli, 2007] has two main consequences. First, the northward motion of the Lut Block and central Iran with respect to Afghanistan [Regard et al., 2004; Vernant et al., 2004; Walker and Jackson, 2004] should be taken up between the Doruneh Fault (Figure 1) and the Kopeh Dagh Mountains with trivial absorption across the northern part of central Iran. Second, part of this motion have to be transferred between the Binalud and Kopeh Dagh mountain ranges, as strike-slip motion along localized major fault systems or in form of distributed deformation (on several faults with comparable slip rates). However, available geological data are insufficient to establish the structural linkage between these deformation domains. Hereafter, we pay a special attention to the structural and geomorphic evidences for active faulting within the transfer region between the Kopeh Dagh and Binalud mountains, i.e., the Meshkan Transfer Zone.

[8] The MTZ forms a triangular-shaped zone $(70 \times 70 \times$ $100 \mathrm{~km}$ ) between three distinct structural domains: (1) the Allah Dagh-Binalud mountains, which can be regarded as the eastern extension of the Alborz mountain ranges [Alavi, 1992], (2) the Kopeh Dagh Mountains to the north, and (3) central Iran to the south (Figure 1). The structural pattern in the Meshkan region is dominated by three fault systems in a triangular configuration with clear crosscutting relationships: (1) the left-lateral, Farhadan Fault system consisting of two ENE trending, strike-slip fault segments, and defining the northern margin of the MTZ against the Allah Dagh mountains, (2) the right-lateral, Chakaneh Fault system, constituted by NNW trending, strike-slip fault segments which affected eastern part of the region and separates the MTZ from the Binalud Mountains, and (3) the reverse Meshkan Fault system, constituted by NW trending, reverse fault segments distributed in the southeastern part of the region defining the southeastern boundary of the MTZ with central Iran (Figure 1). Both the geological and topographic boundaries of the MTZ have been controlled by those fault systems (Figure 2).

[9] In comparison with the surrounding structural domains, the MTZ is clearly different both in geomorphic and geological characteristics (Figure 2). This triangular region is conspicuously less elevated than the Allah Dagh and Binalud mountains (Figure 2). The maximum elevation of the Late Cretaceous-early Paleocene paleoreliefs in the MTZ does not exceed $2300 \mathrm{~m}$ for Yarimja summit, which is about $800 \mathrm{~m}$ lower than the corresponding land surfaces in the Allah Dagh $(3060 \mathrm{~m})$ and Binalud $(3100 \mathrm{~m})$ mountains (Figure 2). In the

Figure 2. (a) Geological map of the MTZ (modified after Amini and Khan Nazer [2000], Ghaemi et al. [1999], and Sahandi [1993]). Fault mapping results from this study based on SPOT 5 and Landsat images. (b) Three-dimensional view of the MTZ showing the general morphology, major fault traces, and Mesozoic paleorelief (based on SRTM digital topographic data). (c) Topographic profile through the MTZ between A and B on (b). Localities: AG, Aghush; AS, AsheqAbad; CK, Chakaneh; FH, Farhadan; GM, Golmeym; KD, Kalidar; KR, Kallar; YM, Yarimja Mountain; ADP and BP, Allah Dagh and Binalud paleoreliefs, respectively; other abbreviations like Figure 1. 

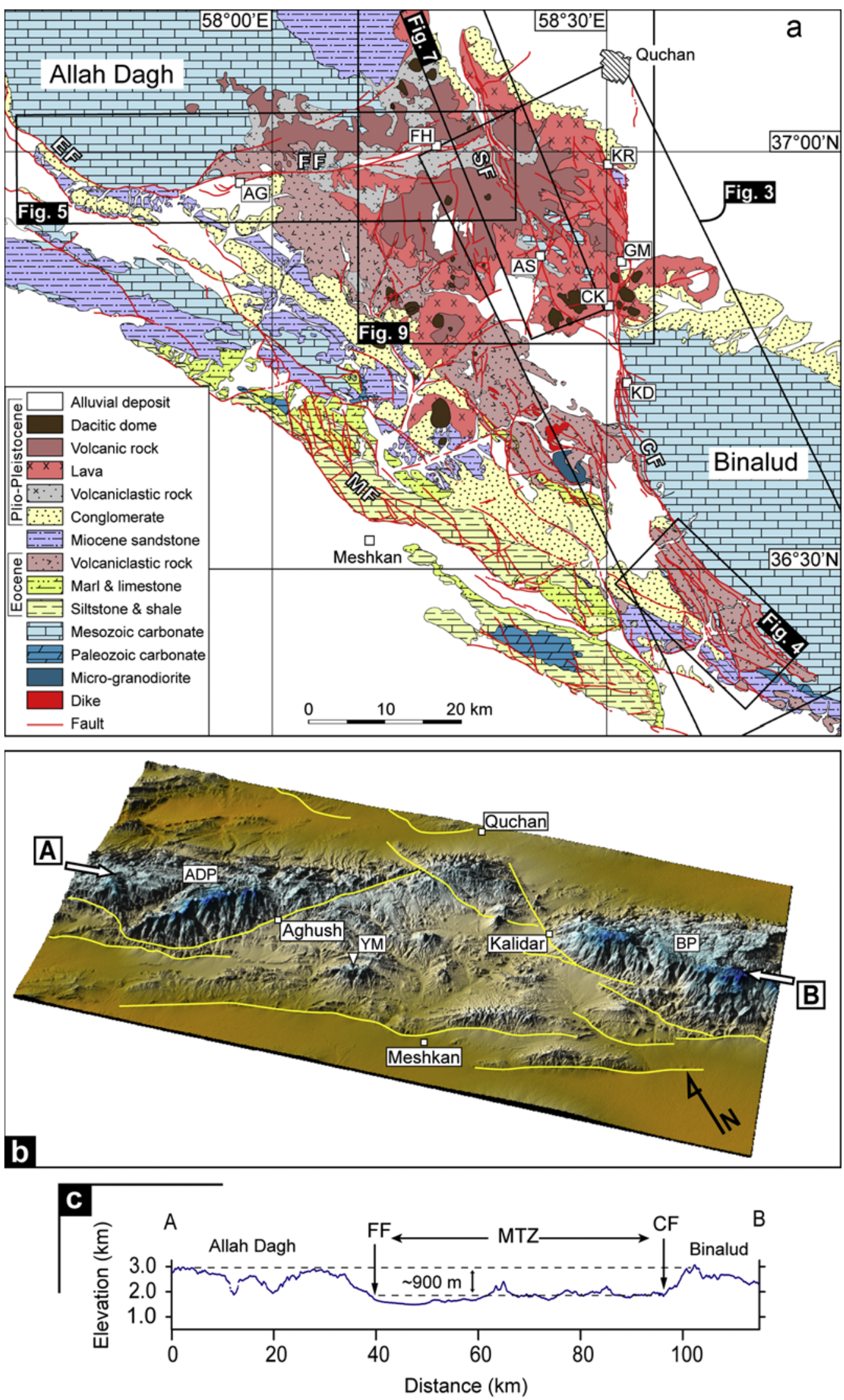

Figure 2 
same way, an abrupt elevation change of roughly $900 \mathrm{~m}$ is observed comparing the average topographic level of the MTZ with respect to the adjacent mountain ranges on the other sides of the Chakaneh and Farhadan fault systems (Figure 2).

[10] The Cenozoic evolution of the Meshkan region is complex; the MTZ has been involved in geological histories of the adjacent structural domains (Alborz, Kopeh Dagh, central Iran) intervened by its own Cenozoic tectonomagmatic episodes. Diverse sedimentary and volcanic rocks, mainly of Tertiary age, are cropping out within the study area. The late Eocene or probably early Oligocene tectonic movements uplifted the entire region [Afshar Harb, 1979]. The Oligocene-Miocene lagoonal to continental sediments fill depressions within syncline fold axis regions constituted by middle-late Eocene layers. These sediments overlie unconformably the folded Eocene rocks and were deformed by the late Miocene compressional movements. The fold axes appear to lie roughly parallel to the northeast dipping fault traces for much of their length. This trend is homogenous throughout the entire region including the Kopeh Dagh, Allah Dagh and Binalud mountain ranges, and probably is representative for uniform episodes of folding since Late Cretaceous. They only have undergone structural deflection in the vicinity of strike-slip faults, given sense of the fault motions. Plio-Quaternary conglomerates have been deposited over the previous folded strata and were gently folded. The folded Eocene and Oligo-Miocene rocks are overlain by thick sequence of late Cenozoic volcanic rocks. In the final stage of the volcanic activity, Plio-Quaternary dacitic-rhyodacitic dome intruded the previous volcanoes or calderas [Amini and Khan-Nazer, 2000]. Regardless some small volcanic domes and dikes, almost all the volcanic activity was concentrated in the northern part of the Meshkan triangle (Figure 2).

[11] According to geological and geomorphic observations, the late Cenozoic deformation within the MTZ has been mainly accommodated by three major fault systems, i.e., the Chakaneh, Farhadan, and Meshkan fault systems (section 3) (Figure 1). The interior of the Meshkan triangle was affected by sparse and distributed faults with maximum segment lengths of about $15 \mathrm{~km}$ (Figure 2). Occupying narrow and linear valleys, these faults have straight traces crosscutting the topography, indicating steeply dipping fault segments. Considering the geometry and orientation of these structures, the Chakaneh and Farhadan fault systems are the best possible candidates to transfer the northward motion of central Iran to the Kopeh Dagh Mountains. Hereafter, we present detailed structural and geomorphic characteristics for these faults, providing evidence for the transferred northward motion of central Iran beyond the Binalud Mountains.

\section{Cenozoic Faulting in the Meshkan Transfer Zone}

[12] In comparison with the adjacent structural domains, the particular geological configuration of the MTZ suggests a complex history of Cenozoic deformation on the boundary fault systems. There is clear evidence for at least two distinct periods of deformation along the fault systems during Cenozoic: (1) an initial fault movement normal to the fault strike, i.e., major component being vertical, creating and then, controlling the margins of the Meshkan Eocene sedimentary basin, and (2) the present-day strike-slip movements affecting post-Miocene fold and thrust structures of the MTZ.

[13] There is a striking contrast between Cenozoic rocks on opposite sides of the Chakaneh and Farhadan fault systems. To the north and east are Middle Jurassic-Early Cretaceous marine carbonate rocks while in the central part, are middle Eocene and early Miocene shallow marine to continental sedimentary rocks (Figure 2). This domain has been affected by late Cenozoic (Miocene to Quaternary) volcanic activities as testified by dike and volcanic domes. The lack of Eocene sedimentation on the surrounding regions indicates direct structural control of the Farhadan and Chakaneh fault systems on the post-Paleocene evolution of the MTZ sedimentary basin. The total vertical slip of the earlier movements along the fault systems is unknown; no rocks of post-Mesozoic have been matched across the fault systems. In the Meshkan triangle, the Mesozoic rocks are overlain by more than $2000 \mathrm{~m}$ of Eocene-Oligocene stratified rocks. These strata have no counterpart along the eastern or northern side of the Chakaneh and Farhadan fault systems, respectively (Figure 2). On the other hand, the present-day average topographic level of reliefs within the MTZ is about $900 \mathrm{~m}$ under the Binalud and Allah Dagh Mesozoic highlands level (Figure 2). Therefore, if the earlier movement was normal to the fault traces, a minimum vertical displacement of $\sim 2900 \mathrm{~m}$ is necessary.

[14] The inception of fault activity along the Chakaneh and Farhadan fault systems may be suggested in the early Cenozoic, but the general history of movement on those fault systems remains unknown. Nevertheless, there is conspicuous geomorphic and geological evidence for active strike-slip faulting along the two fault systems (sections 3.13.3). Slip vectors on major and minor fault planes within Plio-Quaternary deposits confirm the late Cenozoic strikeslip tectonic regime (section 6).

\subsection{Chakaneh Fault System}

[15] The 76-km-long Chakaneh Fault system runs southward from Kallar village (14 km south of Quchan), to the Uqay-Gach gypsum quarry (19 km northwest of Neyshabur) (Figure 3). It cuts Plio-Quaternary volcanic rocks and lies along the eastern boundary of the Eocene sedimentary basin against the Late Cretaceous highlands (Figures 2 and 3). The fault system is a complex, Z-shaped structure that consists of at least three distinct fault segments or fault zones (Figure 3) separated by relatively large (up to $15 \mathrm{~km}$ long and $3 \mathrm{~km}$ wide), and intensely sheared relay zones (Figure 3). Late Cenozoic strike-slip movement along the Chakaneh Fault system is recorded by reorientation and/or displacement of preexisting geological structures (e.g., fold axes, stratigraphic contacts as well as volcanic domes) and geomorphic features such as drainage systems, linear crests and alluvial fans within the fault zones. They are significantly 

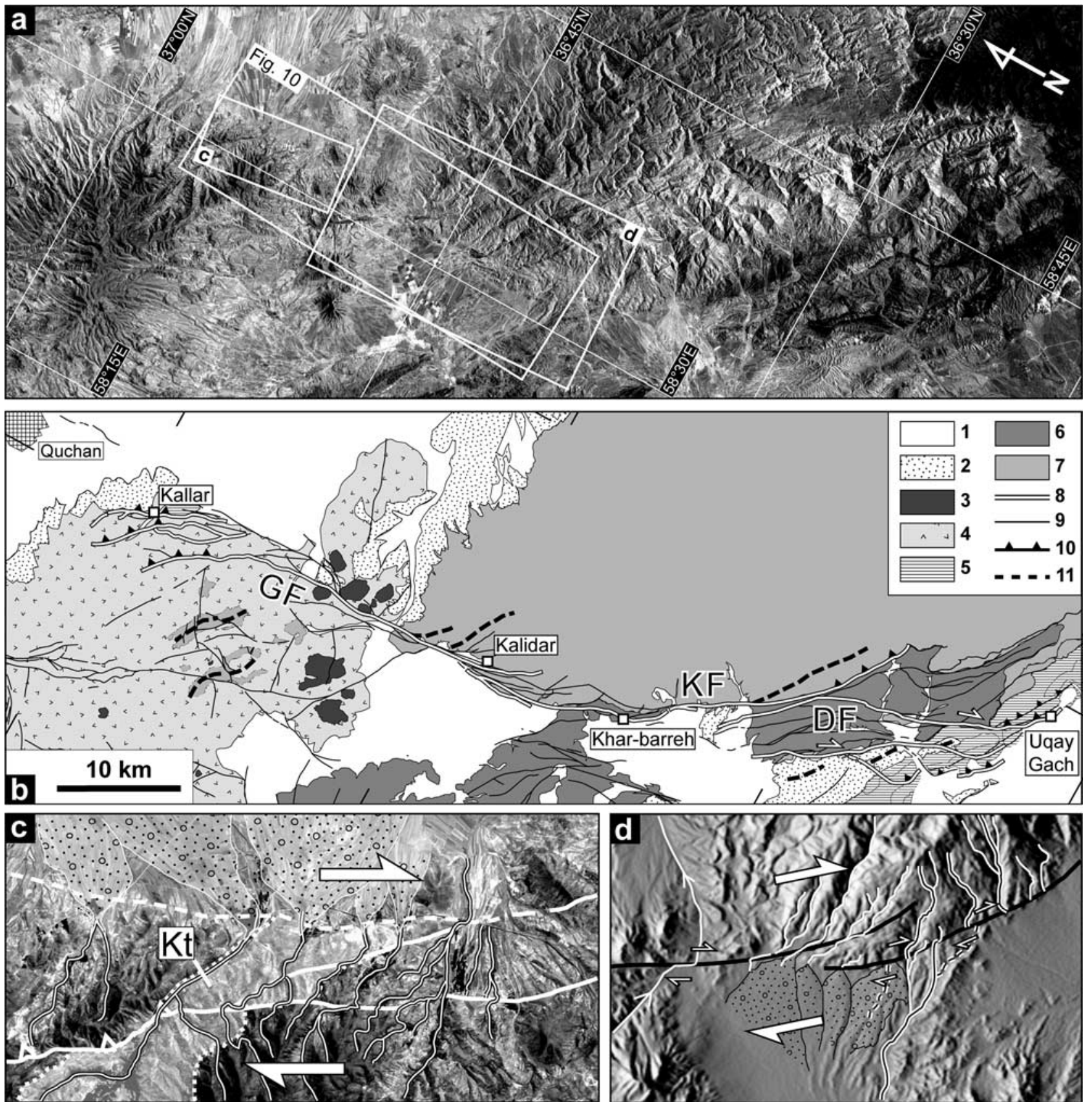

Figure 3. (a) SPOT 5 image of the Chakaneh Fault system. (b) Geological map of the area in Figure 3a showing the detailed geometry, fault segments, and their relay zones. DF, Dâmanjan Fault; GF, Golmeym Fault; KF, Khar-Barreh Fault. Legend indicates 1, Quaternary deposits; 2, Pliocene conglomerates; 3, PlioQuaternary volcanic domes; 4, Plio-Quaternary pyroclastics; 5, Miocene marl and sandstones; 6, Eocene volcaniclastics; 7. Mesozoic carbonates; 8, major Quaternary fault segments of the Chakaneh Fault system; 9, nonclassified fault; 10, reverse fault; 11, fold axis. (c) SPOT 5 image centered on the Golmeym Fault termination indicating right-lateral offsets in a Cretaceous limestone $(\mathrm{Kt})$ and Plio-Quaternary drainage systems. (d) SRTM shaded image centered on the Kalidar region showing sheared or right laterally offset markers such as drainages, ridge crests, and alluvial fans along and within the relay zone between the Golmeym and Khar-Barreh faults. 

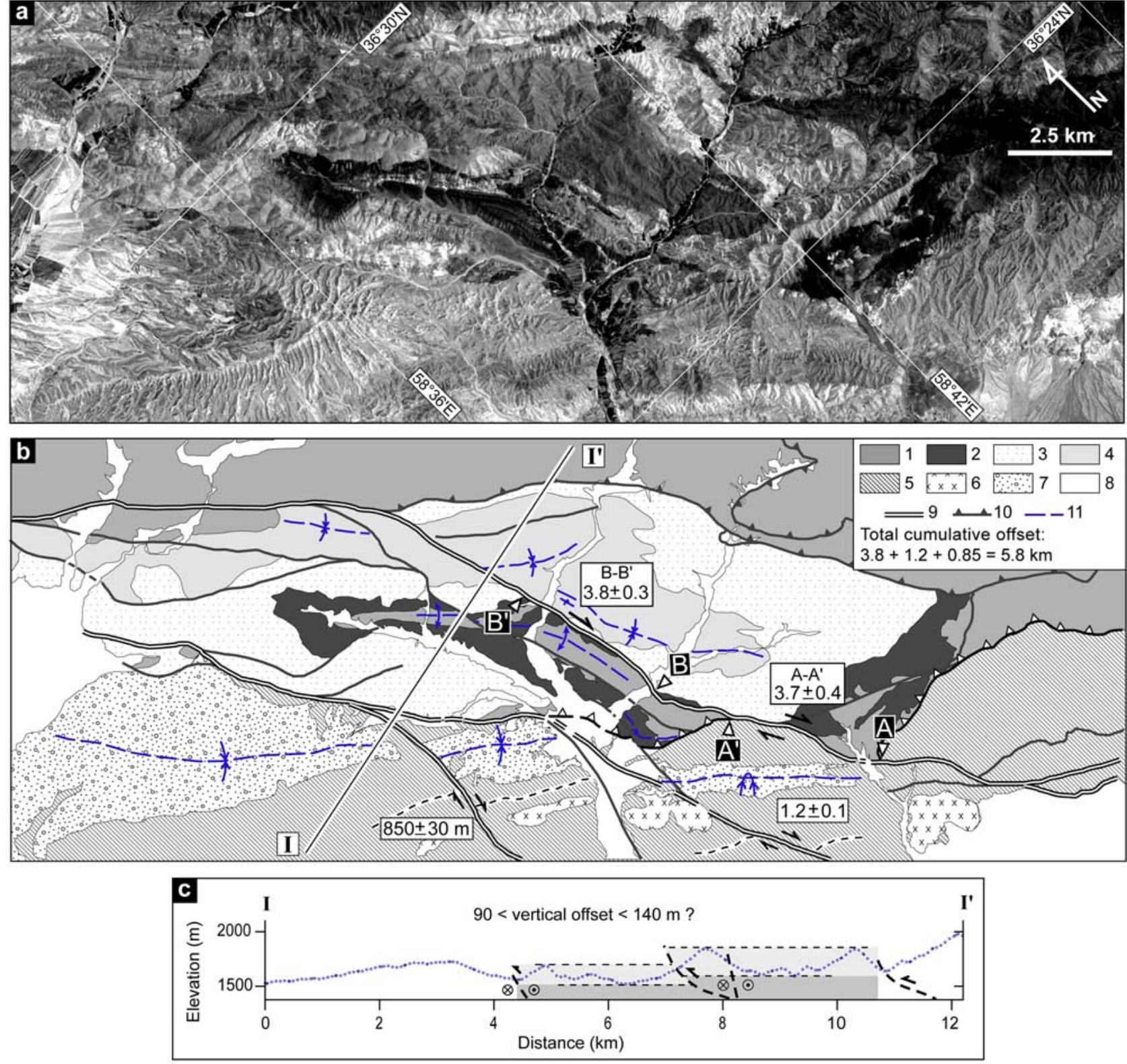

Figure 4. (a) SPOT 5 image of the Dâmanjan region. (b) Detailed geological mapping based on Figure 4a along the Dâmanjan Fault. Numbers within white rectangles are right-lateral offset values for each pair of successive piercing points (A-A', B-B') or stratigraphic features (thick white lines); values are in kilometers. I-I' shows the location of topographic profile across the fault zone. Legend indicates 1, undifferentiated rocks (Mesozoic and early Eocene); 2, volcanic rocks; 3, marl and sandstones; 4, conglomerates ( 2 to 4 are Eocene rock units); 5, Miocene and Pliocene rocks; 6, post-Miocene extrusive volcanic rocks; 7, Plio-Quaternary conglomerates; 8, Quaternary deposits; 9, fault; 10, thrust fault; 11, fold axis. (c) Topographic profile across the fault zone on the basis of SRTM digital topographic data. Minimum and maximum topographic levels on both sides of the Dâmanjan fault are marked by the light and dark gray shaded areas.

rearranged within several hundred to thousand meters of the fault zone and particularly within the relay zones (Figure 3).

[16] Detailed geological mapping on SPOT 5 satellite images provides convincing evidence for large cumulative strike-slip offsets along the Chakaneh Fault system. Along the Dâmanjan fault segment (Figure 4), folded volcanosedimentary layered rocks of Cenozoic age show a rightlateral cumulative displacement of $3.8 \pm 0.4 \mathrm{~km}$. Total right-lateral cumulative offset along the entire fault zone reaches a sum of $5.8 \pm 0.8 \mathrm{~km}$ recorded by different stratigraphic markers offset by three fault strands (Figure 4). 

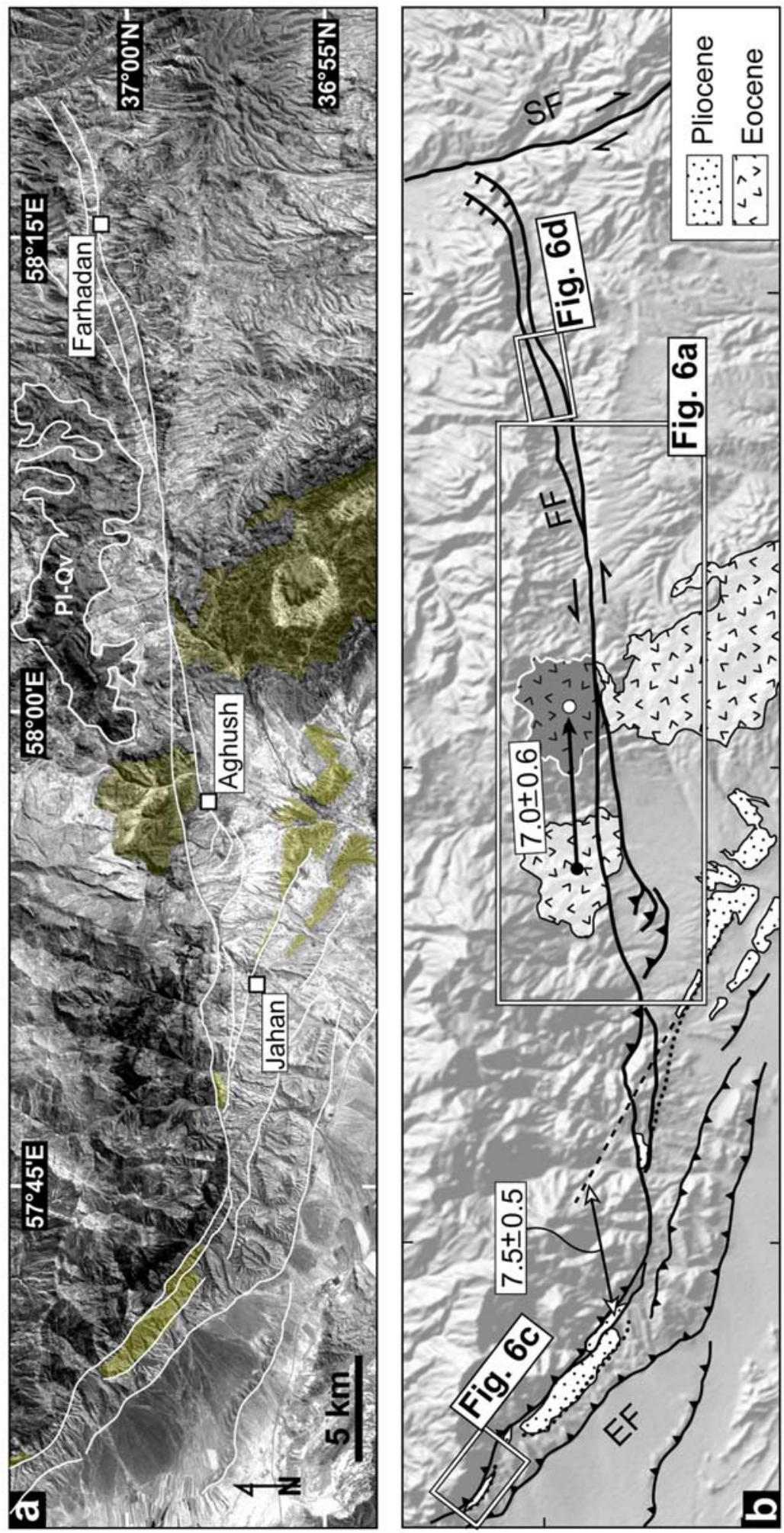

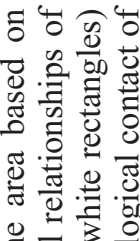

준

世总䓃

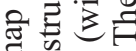

ㅍㅀ용

응 $\stackrel{0}{2}$

응 岂

品苍艺苛

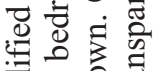

믈 त्ञ

क

อิ을

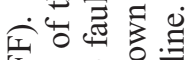

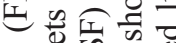

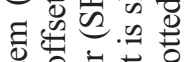

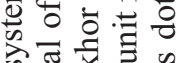

कि तै क

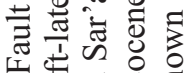

10

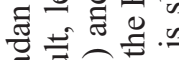

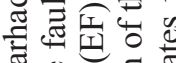

里

ङ

范要

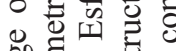

范范

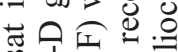

守这吕

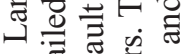

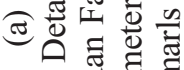

ம

记焉. .00. 

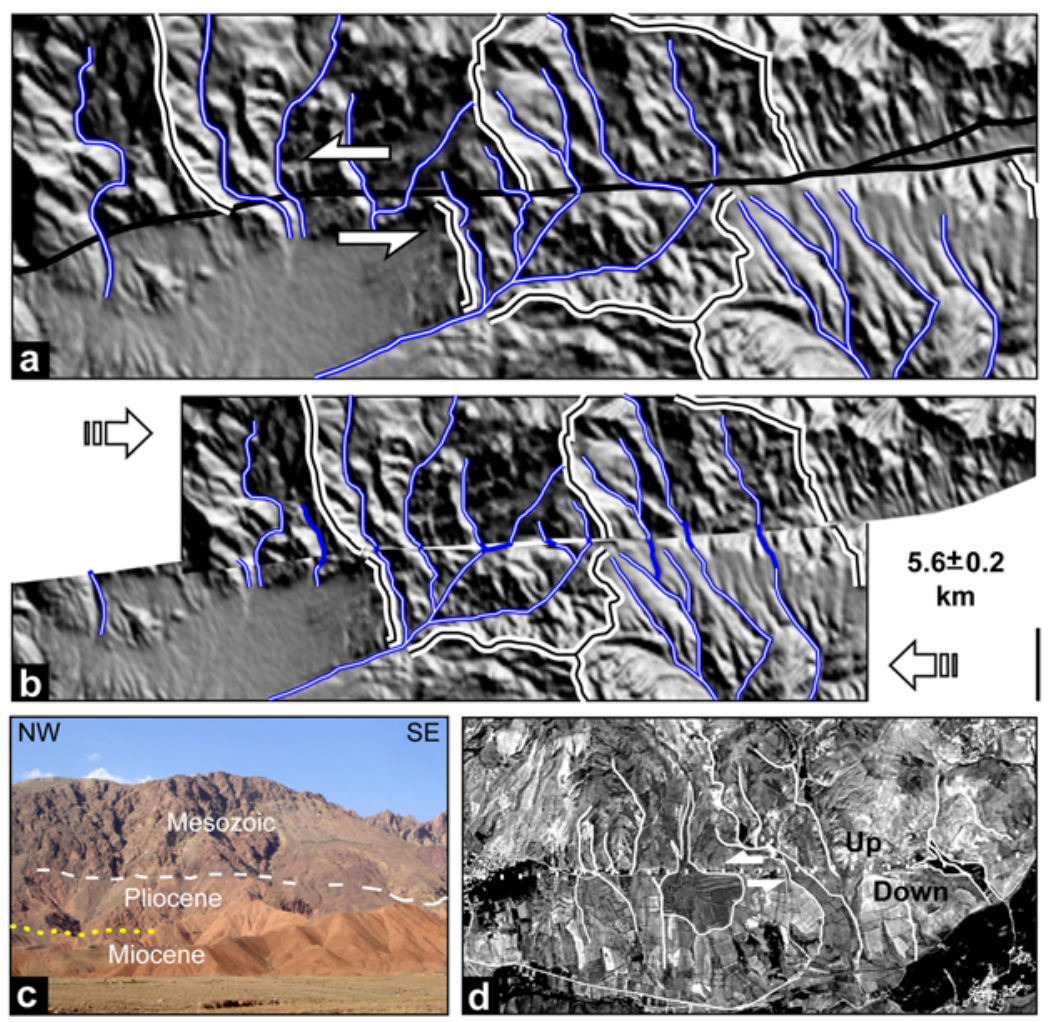

Figure 6. (a) and (b) Morphotectonic reconstruction of two drainage basins and their associated streams left laterally offset along the fault trace before (Figure 6a) and after the reconstruction (Figure 6b). (c) A field photograph showing that the Mesozoic limestone is thrust over the Pliocene conglomerate. Location of the photograph is marked on Figure 5b. (d) SPOT 5 image centered on the eastern segment of the Farhadan Fault system indicating deflected and/or beheaded streams, as well as left laterally offset alluvium landforms (fan and bed streams).

On both sides of the Dâmanjan fault, equivalent geological units are roughly at the same elevation, suggesting negligible $(<3 \%)$ coeval vertical component of displacement on the fault, i.e., nearly pure strike-slip faulting (Figure 4). The inception date of dextral strike-slip faulting along the Chakaneh Fault system can be deduced using stratigraphic ages of the offset geological units. In the southern part of the fault zone, upper Eocene layers are thrusted over Miocene rocks, deforming gently folded Plio-Quaternary conglomerates into an overturn synclinal fold structure (Figure 4). The thrust contact is right-laterally displaced by the eastern fault strand (A-A' piercing points in Figure 4). Along the central and western fault strands, the synclinal axis is displaced as approximately the same order as early Miocene rocks (Figure 4). Considering these geological relationships, one can conclude that right-lateral strike-slip faulting along the Chakaneh Fault system started during (not earlier than) Pliocene.

\subsection{Farhadan Fault System}

[17] The Farhadan Fault system runs along the northern boundary of the MTZ. This $65-\mathrm{km}$-long fault system extends west-southwest from $6 \mathrm{~km}$ east of Farhadan village to the village of Jahan in the southwest. In that area, the fault merges with the Esfarayen Fault (Figures 1 and 5). The
Farhadan Fault system was partly mapped by Amini and Khan-Nazer [2000] and referred as the Bash Mahalleh Fault. In the present study, detailed mapping allow characterizing the whole fault system, which is referred to as the Farhadan Fault system. This fault system consists of two principal faults diverging westward (Figure 5). The eastern one extends on roughly $40 \mathrm{~km}$ to the west of Farhadan village, and ends into a thrust-bend termination zone (Figure 5). The western strand runs on $\sim 25 \mathrm{~km}$ west from Aghush village, joining the Esfarayen Fault at the western end.

[18] Late Cenozoic movement along the Farhadan Fault system is mainly strike-slip. Along most of its length, the Farhadan Fault system cuts through Quaternary features and provides convincing evidence for its Quaternary activity. The fault system is indicated by linear traces, deflected and beheaded streams, and obvious lithologic contrasts (Figures 5 and 6). Nearly continuous south facing scarps in Quaternary deposits are observed along the main active fault trace. These scarps probably result from vertical component of displacement along the fault. Left-lateral offset streams, ridges, and rock units are representative for dominant strikeslip motions along the fault system. Around Aghush village, the oldest streams incised in Plio-Quaternary pyroclastic terrains indicate cumulative offset of $5.6 \pm 0.2 \mathrm{~km}$ along 
the Farhadan Fault system (Figure 6). In the same area, the restoration of total offset in upper Eocene volcanic units reveals a maximum cumulative displacement of $7.0 \pm 0.6 \mathrm{~km}$ along the fault. More to the west, the same order of displacement $(7.5 \pm 0.5)$ is observed in stratigraphic contact between upper Miocene and Pliocene beds (Figure 5), indicating a Pliocene inception age for the left-lateral movement along the Farhadan Fault system.

\subsection{Sar'akhor Fault}

[19] South of Faruj, the SE trending Sar'akhor Fault cuts through the Sar'akhor Mountain (Kuh-e Sar'akhor) over a length of $34 \mathrm{~km}$ (Figures 1 and 7). The relatively straight fault trace is occupied by two linear valleys on both sides. The Farhadan Fault ends northeast intersecting the Sar'akhor Fault. North of the Sar'akhor Mountain, sharp fault traces underline segments that extend through Plio-Quaternary volcanic rocks parallel to the main trace of the fault (Figure 8). Conspicuous geomorphic features such as offset and/or perturbed drainage basins, deflected gullies and streams as well as outcrop-scale knickpoints represent right-lateral strike-slip fault displacements ranging from 80 to $900 \mathrm{~m}$ along the fault traces (Figure 8).

[20] Even if the main fault trace is relatively obvious on digital topography and satellite images, the morphologies associated to the fault are relatively degraded and weakly preserved due to erosion and a long human activity. This effect is even more severe along the northwest midlength of the fault than its southeastern end. However, the preserved fault morphology along the central and southeastern parts provides evidence for the mechanism and amount of cumulative fault displacement. Close to its southeastern termination, the Sar'akhor Fault offsets a $\sim 9-\mathrm{km}-$ long anticline near Asheq-Abad village (Figure 7). The anticline is constituted by Cretaceous limestone (Tirgan formation) and is surrounded by Plio-Quaternary lavas. The assemblage is right laterally displaced of $2.7 \pm 0.3 \mathrm{~km}$ by the Sar'akhor Fault (Figure 7). Despite, there is no clear geological evidence for coeval vertical fault displacement; it can be estimated using geometric reconstruction of the conicshaped Sar'akhor Mountain morphology. Considering the present-day shape of the Sar'akhor volcano (Figure 9), one can assume that volcanic materials sourced from the volcano were distributed on a uniform slope around the Sar'akhor Mountain. Accepting this assumption, vertical offset can be estimated through a restoration of the topography affected by the fault. Figure 9 presents topographic contour maps of the Sar'akhor Mountain before and after the restoration. The present-day topographic contours of the Sar'akhor Mountain show obvious apparent offsets along the Sar'akhor Fault. The offsets are opposite at the two fault ends, and the surface of each given topographic level on the northeastern side of the fault is waster than its equivalent on the southwestern side (Figure 9). Theoretically, this feature can be described as differential vertical displacement across a dissected conic- or dome-shaped structure, which is consistent with the rounded geometry of the Sar'akhor Mountain (Figure 9). Therefore, the amount of vertical displacement can be estimated by numeric restoration of each virtually displaced contours area achieving the initial conic form of the mountain. Such a topographic reconstruction reveals an upward vertical displacement of about $110 \mathrm{~m}$ for the northeastern side (block) of the Sar'akhor Fault (Figure 9), that is to say less than $5 \%$ of its cumulative lateral offset $(\sim 2.5 \mathrm{~km})$.

[21] To the northwest, the Sar'akhor Fault surface expression disappears $10 \mathrm{~km}$ southeast of Faruj city, in south flank of the Atrak valley (Figure 1). The morphology of the valley has been reworked by human activities and there is not preserved geomorphic evidence for the continuation of the fault across the valley. The other side of the valley is affected by the Baghan and Quchan faults, which are the major strike-slip faults of the Kopeh Dagh [e.g., Afshar Harb, 1979; Hollingsworth et al., 2006; Shabanian et al., 2009; Tchalenko, 1975]. The Baghan and Quchan faults start 15 and $7 \mathrm{~km}$ north of the northern termination of the Sar'akhor Fault, respectively (Figure 1). Even though subtle geomorphic features have been proposed by Hollingsworth et al. [2006], as evidences of their thrust-bend termination in the Atrak Valley, the southern end of the Baghan and Quchan faults remains unclear. A meticulous analysis of SRTM digital topographic data and SPOT 5 image reveals a delicate right-lateral geomorphic offset, where a NE trending hill (Neogene marls) appears to be affected by the inferred continuation of the Baghan and/or Sar'akhor fault trace crossing the Atrak valley (Figure 9). All together, the geological and geomorphic observations lead us interpreting the Sar'akhor Fault as a possible candidate for the southern extension of the Baghan Fault beyond the Atrak valley.

\section{Morphotectonic Investigations Along the Chakaneh Fault System}

[22] The geomorphic expression of strike-slip faulting on the Chakaneh Fault system is characterized by conspicuously offset landforms such as drainage systems, linear crests and alluvial fans. Around the village of Kalidar, valleys show systematic dextral offsets of about $2 \mathrm{~km}$ along the relay zone between the northern (Golmeym) and central (Khar-Barreh) fault segments (Figure 10). The streams are deflected parallel to shutter ridges within and along the fault zone forming trapped alluvial basins behind shutter ridges

Figure 7. (a) SPOT 5 image of the Sar'akhor Mountain (SM). SF, Sar'akhor Fault; SV, Sar'akhor volcano. (b) Morphotectonic map of the Sar'akhor Fault based on Figure 7a. The inferred continuation of the Baghan and Sar'akhor faults is marked by black dotted line. (c) SPOT 5 image of the Asheq-Abad anticline deformed along the Sar'akhor Fault (double, white line). Double, black line presents anticline axis and dotted lines are drainages deflected along the fault trace. A, B, and C are the piercing points used for offset measurements. Kt, Cretaceous limestone; Pl-v, Plio-Quaternary lava. (d) Field photograph of two right laterally deflected gullies and associated knickpoints (K1 and K2) along the northeastern Quaternary trace of the Sar'akhor Fault. Location of the photograph is marked on Figure 7a. Note that Figures 7a and 7b have the same frame. 

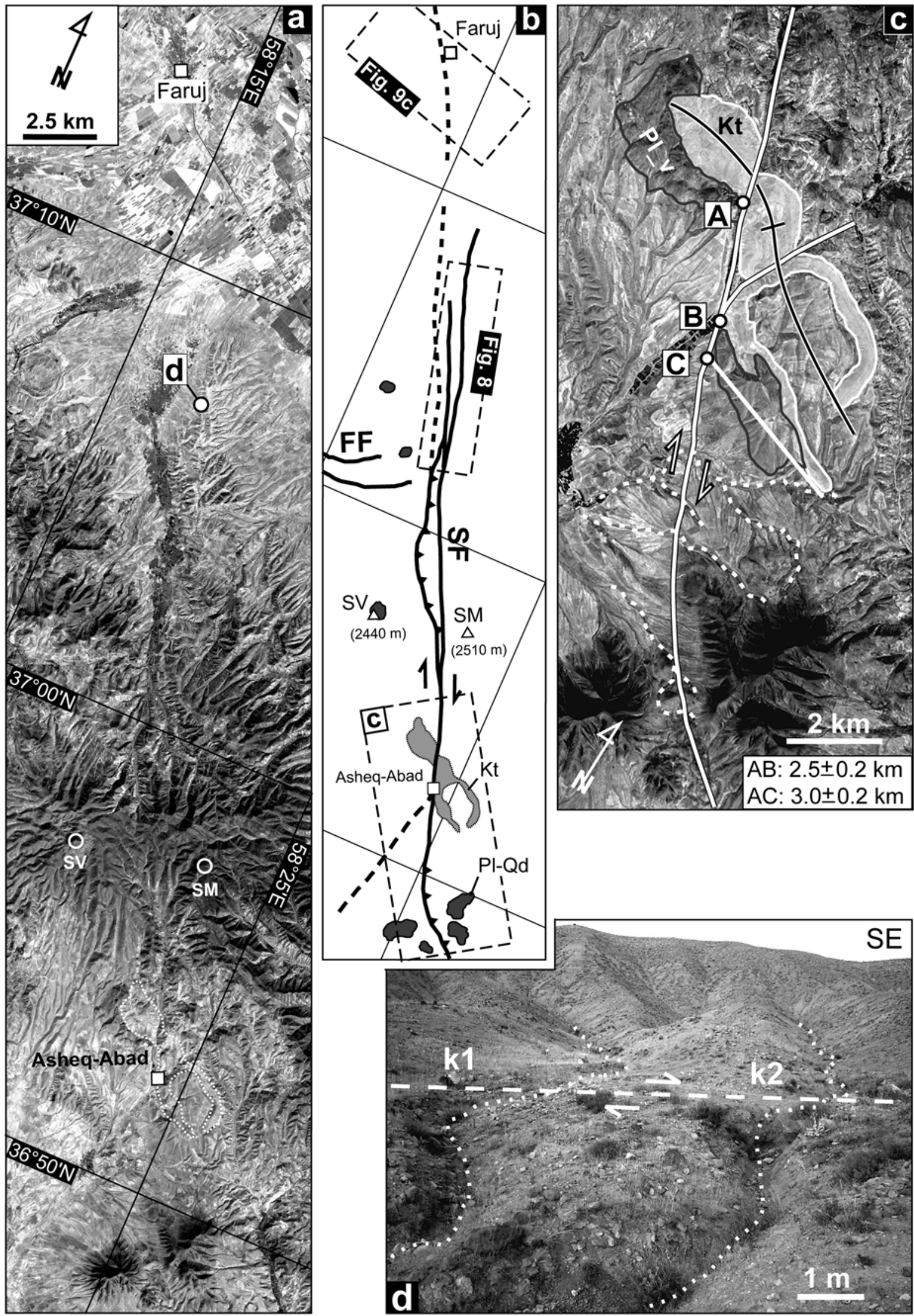

Figure 7 

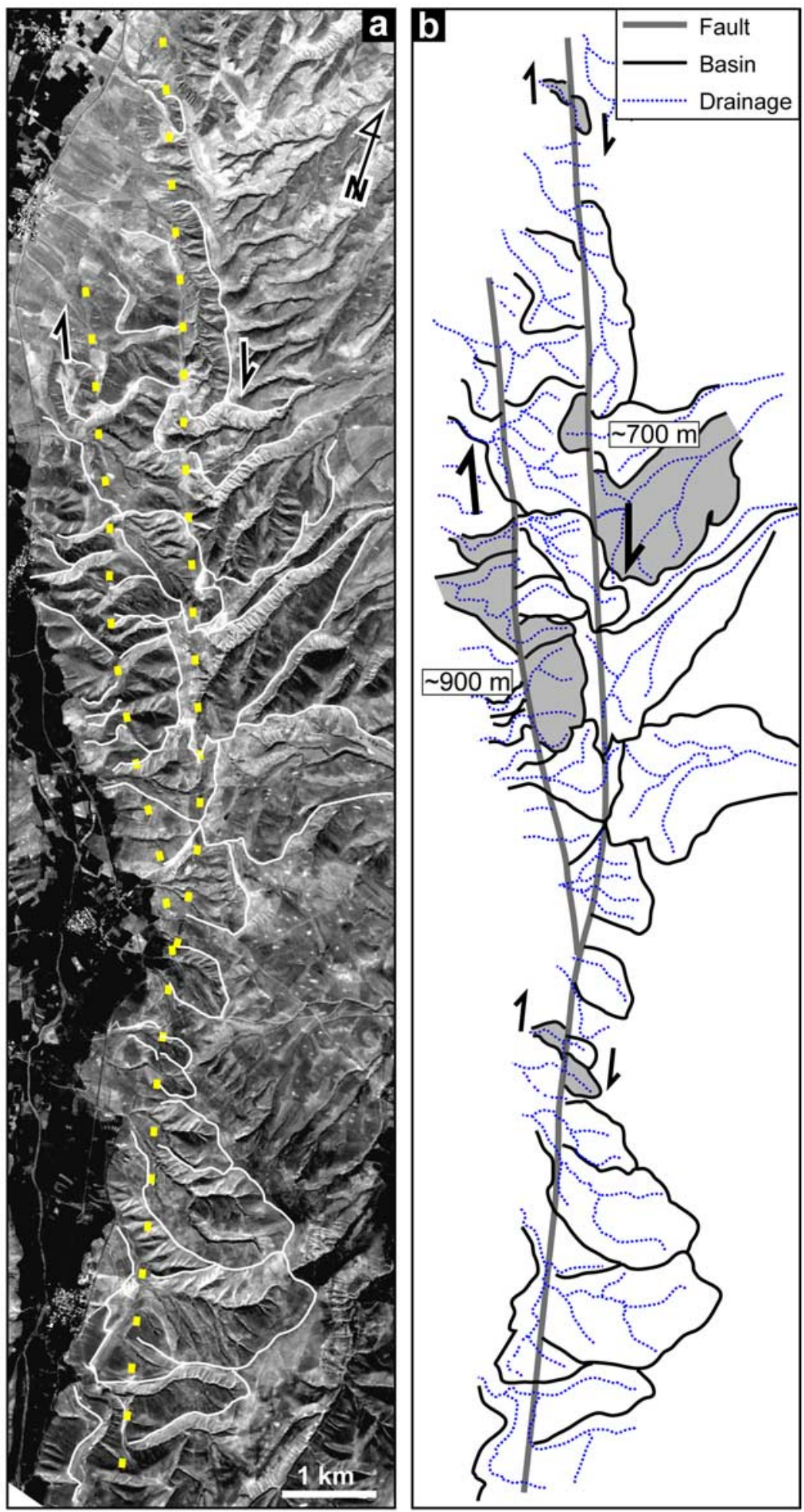

Figure 8. (a) SPOT 5 image of the Sar'akhor Quaternary fault traces (yellow, dotted line). (b) Morphotectonic map of drainage systems (drainage basins and streams) affected by the Sar'akhor Fault (based on Figure 8a). Rectangles show the values of possible right-lateral offsets deduced from dissected basins (gray polygons). 

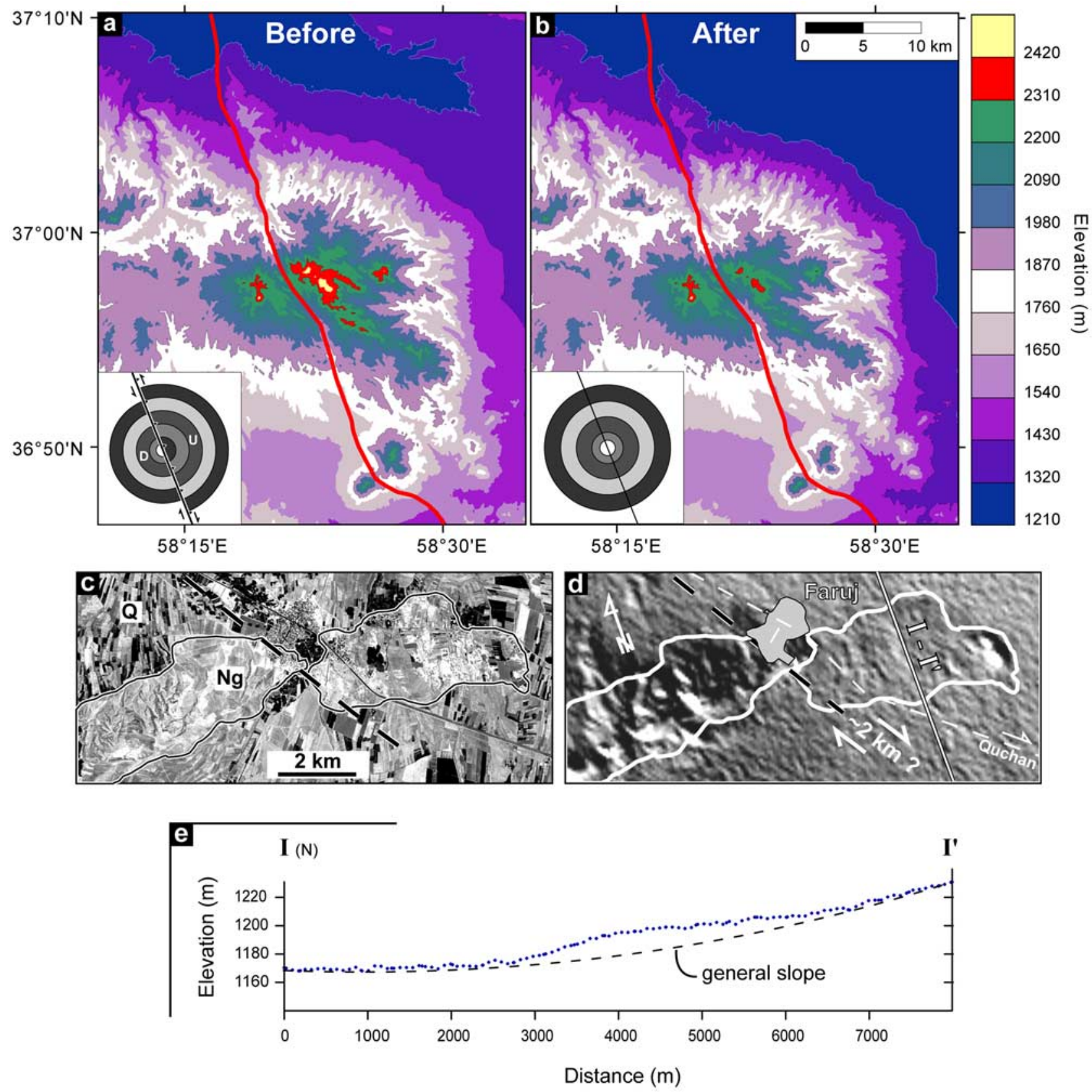

Figure 9. ( $\mathrm{a}$ and $\mathrm{b}$ ) Topographic restoration of vertical displacements recorded by the Sar'akhor volcano (SRTM data) before (Figure 9a) and after the reconstruction (Figure 9b). A simple geometric model is presented in the lower left corner of each image. (c) SPOT 5 image centered on a right-lateral offset along the inferred continuation of the Baghan Fault (black, dotted line), within the Atrak valley. $\mathrm{Ng}$ and Q are the Neogene and Quaternary deposits, respectively. (d) SRTM shaded image of the same area as Figure 9c. (e) A topographic profile (I-I' on Figure 9d) showing morphology of the affected hill on eastern fault block. See Figures 2 and 7 for location of Figures 9a and 9c, respectively.

(Figure 10). A key site is selected along the Golmeym Fault, between Golmeym village and Chakaneh city. In that area, the Golmeym Fault splays northwardly to several fault strands forming a 1500-m-wide fault zone. Along the main strand of the fault, several streams indicate systematic rightlateral offsets of $1400 \pm 50 \mathrm{~m}$, while the Chakaneh River shows a maximum geomorphic offset of $1600 \pm 200 \mathrm{~m}$ (Figure 10). These offset values are lower than the observed offsets more to the south, in the Kalidar region (Figure 10), indicating the northward diminution of displacement along the Chakaneh Fault system. 

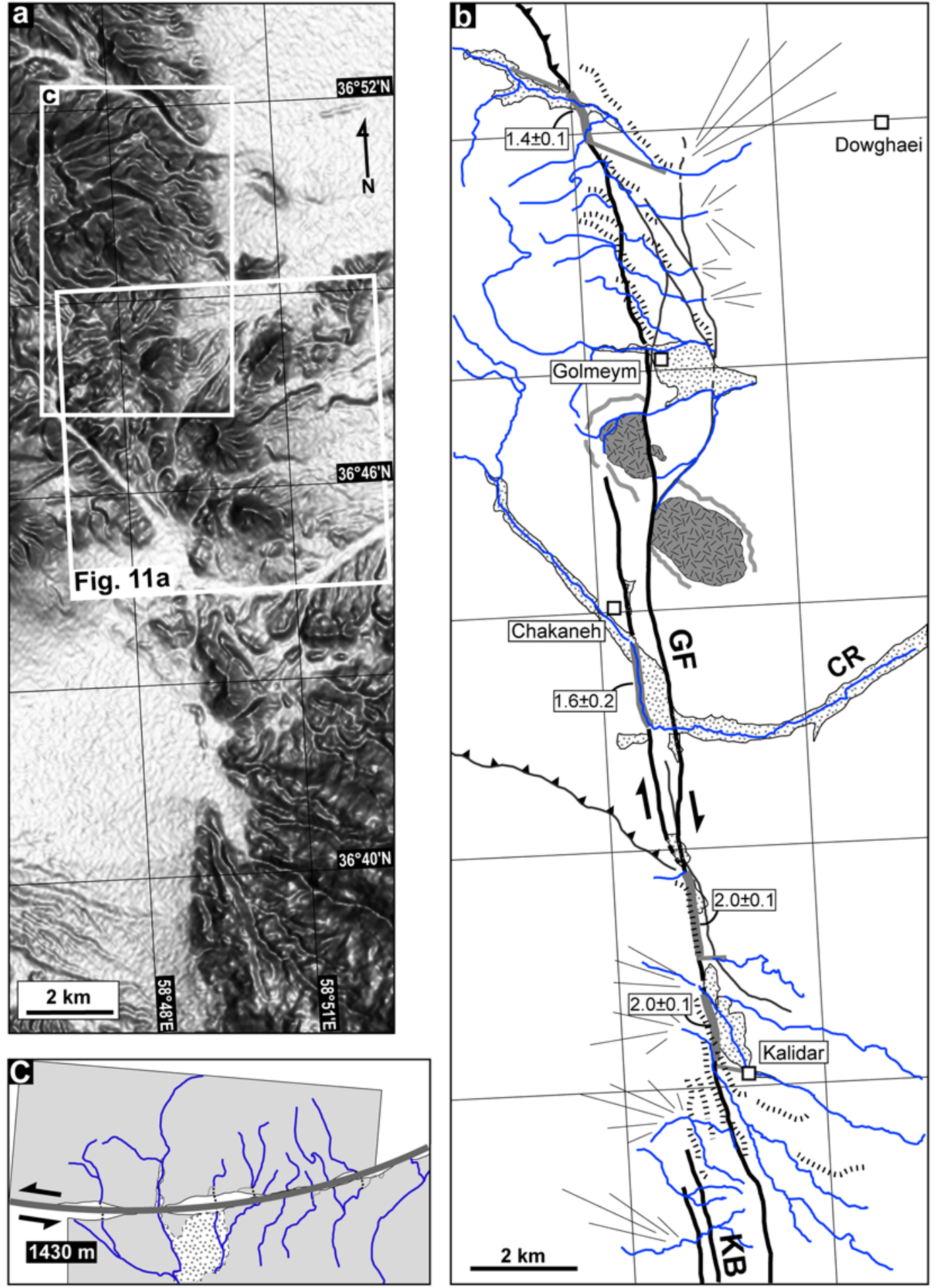

(1)

Figure 10. (a) SRTM shaded image of the Golmeym Fault. (b) Morphotectonic map of the Golmeym Fault based on SPOT 5 images presenting major fault segment traces (thick, black line), minor faults (thin, black line), deflected drainages (thin, blue line), shutter ridges (thick, dotted line), trapped alluvial basins and bed streams (dotted polygon), and a right laterally offset volcanic dome (gray polygon). Gray lines show external limit of the tilted strata around the dome. Offset values are expressed in kilometers. CR, Chakaneh River. (c) Final reconstruction of drainage systems deflected along the Golmeym Fault. Note that Figures $10 \mathrm{a}$ and $10 \mathrm{~b}$ have the same frame. 

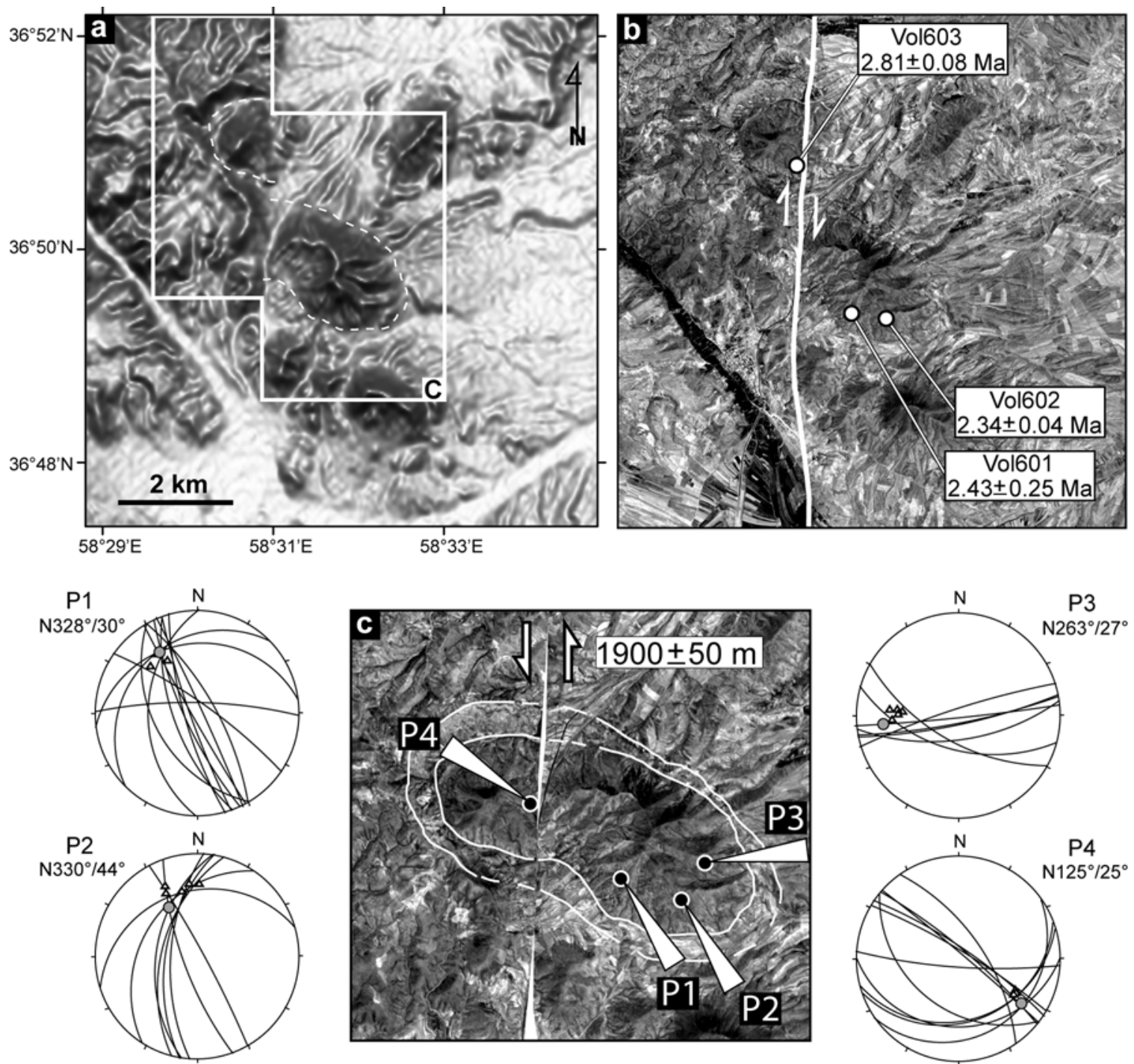

Figure 11. (a) SRTM shaded and (b) SPOT 5 images of the volcanic dome offset along the Golmeym Fault (white line). Names and location of samples as well as their associated radiometric $\left({ }^{40} \mathrm{Ar}{ }^{39} \mathrm{Ar}\right)$ ages are marked on Figure 11b. (c) The initial form of the dome after the fault offset restoration. The frame of this figure (before reconstruction) is presented in Figure 11a. P1 to P4 are average axes of the lava columns measured on the field that pointed in the axis plunge directions. Stereograms represent Smith projection of the measured geometry of cooling features developed in the dome: $\beta$ axis (circle) and column axis (triangles).

[23] Despite abundant offset markers over whole length of the fault, there are a few landforms providing both geomorphic feature offset and absolute dating possibilities. For instance, along the Golmeym River, surface exposure dating using in situ-produced cosmogenic ${ }^{10} \mathrm{Be}$ was unsuccessful due to intense erosion of the surface. However, a typical landform is found north of Chakaneh city where, the Golmeym Fault runs through volcanic dome structures. In this area, the fault right laterally displaces a dacitic dome (Figures 10 and 11). This is one of the rare geomorphic features providing favorable conditions for both landform dating $\left({ }^{40} \mathrm{Ar} /{ }^{39} \mathrm{Ar}\right)$ and cumulative offset measurements (section 4.1).

\subsection{Cumulative Offset Recorded by the Volcanic Dome}

[24] North of Chakaneh city, a series of volcanic structures comprising of distinct dacitic domes is affected by the Golmeym Fault. The domes are elliptical in shape, with NW trending elongated axis. The largest one is clearly truncated and right laterally offset by the fault (Figure 11). To avoid misinterpreting two distinct volcanic domes as a truncated structure, dependency of the domes (suggested to be parts of the same structure) was examined by combined geomorphic and structural analysis complemented by ${ }^{40} \mathrm{Ar} /{ }^{39} \mathrm{Ar}$ dating (section 5).

[25] During extrusion process, older layered rocks (Cretaceous limestones) are pierced by the lava dome tilting 

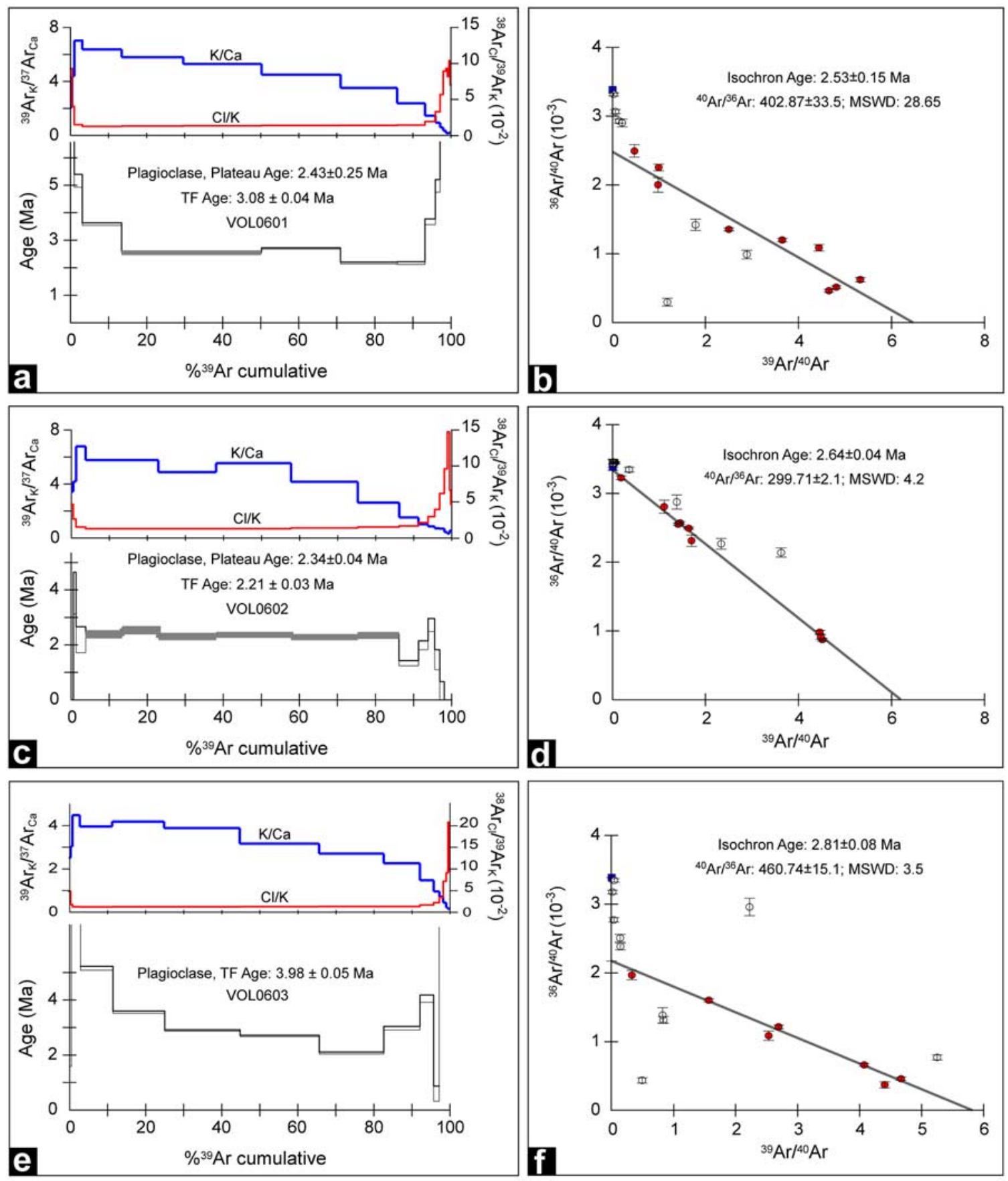

Figure 12. The ${ }^{40} \mathrm{Ar}{ }^{39} \mathrm{Ar}$ step heating results from the offset volcanic dome. Sample names are marked middle of Figures 12a, 12c, and 12e. See Figure 11 for sample locations.

them over to create a clear stratified boundary around the volcanic masses. This boundary is also cut and displaced along the fault (Figures 11 and 12) indicating that the two volcanic masses were formerly a single dome structure. Confirming our assertion, we verified consistency of the internal structure of the lava dome in the field. Thermal cracks develop perpendicularly to the isothermal surfaces and to the external surfaces in contact with air and wall rocks. The orientation of the columns relates to the cooling history of the mass. When viscous dacitic or rhyolitic magmas are extruded, they form a cumulo dome. A section across a lava dome would have a concentric, onion-like structure with radiating columnar joints. In a reconstitution model, two separates blocks of a single dome must fit geometrically. Structural analysis of the orientation of column axes and associated columnar joints was down using measured geometric data at four localities on the offset domes, both sides of the fault (Figure 11). The centerward converging column pattern in the main body of the volcanic dome was examined at three localities 
Table 1. Dating Results From ${ }^{40} \mathrm{Ar} /{ }^{39} \mathrm{Ar}$ Radiochronology for Whole Rock ${ }^{\mathrm{a}}$

\begin{tabular}{|c|c|c|c|c|c|c|c|c|c|}
\hline Sample & $\begin{array}{c}\text { Longitude } \\
\left({ }^{\circ} \mathrm{E}\right)\end{array}$ & $\begin{array}{l}\text { Latitude } \\
\left({ }^{\circ} \mathrm{N}\right)\end{array}$ & $\begin{array}{l}\text { Total Fusion } \\
\text { Age }\end{array}$ & $\begin{array}{c}\text { Plateau Age (PA) } \\
\text { or Simple Mean } \\
\text { Age (SMA) }\end{array}$ & Isochron Age & ${ }^{40} \mathrm{Ar} /{ }^{36} \mathrm{Ar}$ & MSWD & Preferred Age & Remark \\
\hline VOL601 & 58.525 & 36.823 & $3.08 \pm 0.04$ & $2.43 \pm 0.25(\mathrm{SMA})$ & - & - & - & $2.43 \pm 0.25$ & \\
\hline VOL602 & 58.533 & 36.823 & $2.21 \pm 0.03$ & $2.34 \pm 0.04(\mathrm{PA})$ & $2.64 \pm 0.04$ & 300 & 4.2 & $2.34 \pm 0.04$ & \\
\hline VOL603 & 58.516 & 36.844 & $3.98 \pm 0.05$ & - & $2.81 \pm 0.08$ & 461 & 3.5 & $2.81 \pm 0.08$ & Maximum age \\
\hline
\end{tabular}

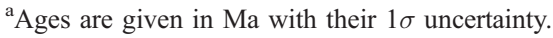

selected on different sides of the southern dome segment. The fourth one was chosen on the free-face side of the northern segment that is suggested to be a transversal section along the Golmeym Fault exposing the internal structure of the volcanic dome. The measured data in each site are plotted on separate stereograms (Figure 11) in which, the column orientation is independently indicated by both intersection of the columnar joint planes ( $\beta$ diagram axis) and column axes directly measured in the field. In stereograms, similar geometry for both the $\beta$ diagram and column axes demonstrates that the measured structural data can be confidently considered as igneous columnar features and not tectonic jointing (Figure 11). The centerward converging column pattern of the southern dome segment is deduced from the three first stereograms. The fourth one has inappropriate (centerward diverging) orientation with respect to the northern dome geometry, when assuming it an individual structure. Restoring the initial dome shape
(Figure 11), the four positions show a converging pattern of the cooling columns toward the initial dome center. This observation reveals that the two segments belong to a single lava dome displaced by the Golmeym Fault and their offset is representative for the cumulative post intrusion fault displacement. The reconstruction of former dome shape shows a cumulative right-lateral offset of $1900 \pm 50 \mathrm{~m}$ along the Golmeym Fault (Figure 11)

\section{The ${ }^{40} \mathrm{Ar} /{ }^{39}$ Ar Dating}

\subsection{Sampling and Analytical Procedure}

[26] Three rock samples were collected from the two isolated parts of the offset dacitic dome (section 4). The sample localities and their characteristics are presented in Figure 11 and Table 2a. The samples were collected from the less weathered parts of the lava masses. Detail analytical

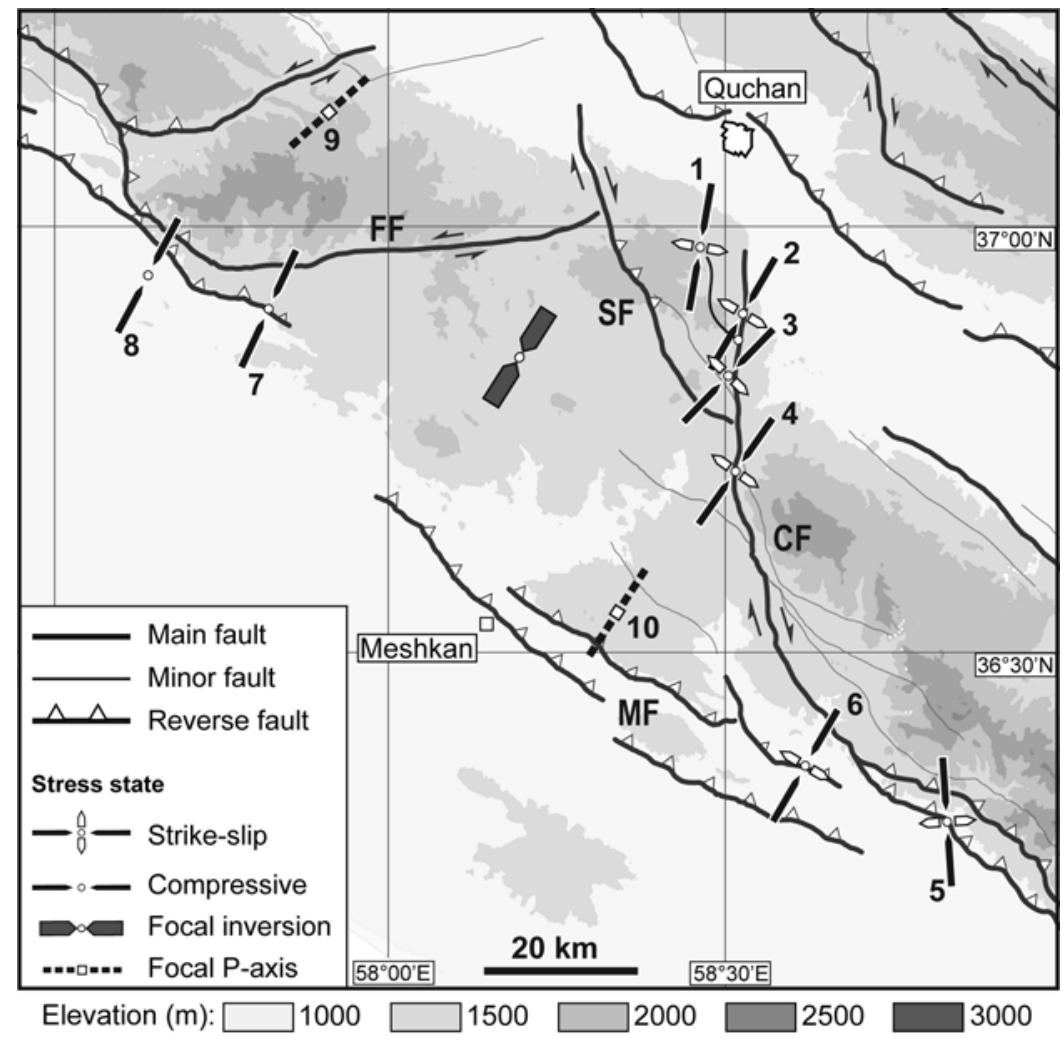

Figure 13. Azimuths of $\sigma_{1}$ (maximum stress axis) for the strike-slip and compressional stress regimes deduced from the individual fault slip inversions given in Table 2a and Figure 14. 

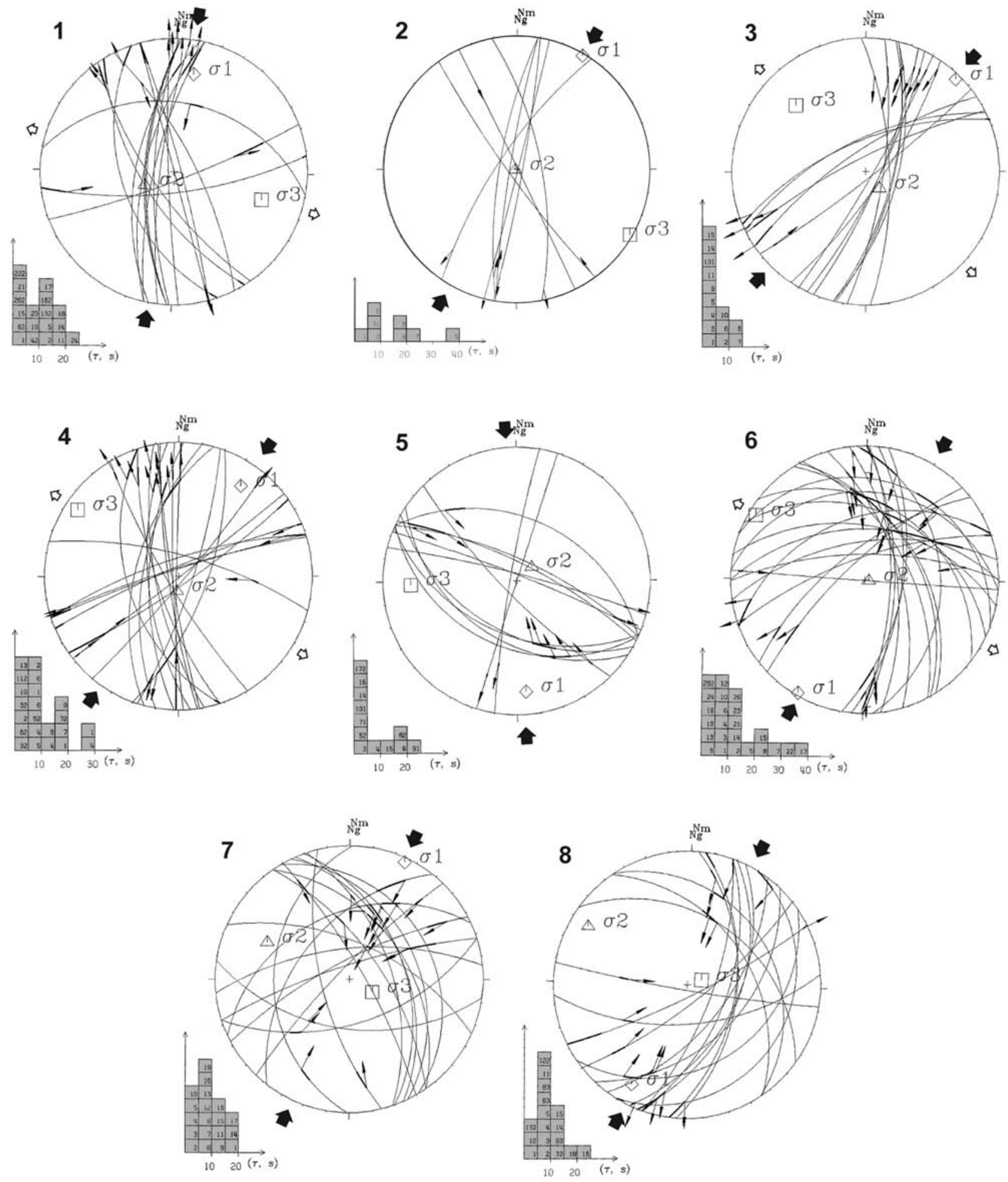

Figure 14. Lower hemisphere stereograms of fault slip data from the MTZ together with inversion results presented in Table 2a. Numbers refer to site names marked in Figure 13, and in Tables 2a and $2 \mathrm{~b}$. Individual fault planes and measured slip vectors (arrows on fault planes) at each site are plotted. Large arrows outside stereograms represent the azimuth of $\sigma_{1}$. Histograms show distribution of deviation angles between the measured and calculated slip vectors [e.g., Bellier and Zoback, 1995]. 
Table 2a. Results of Stress Tensor Inversion for Slip Data Representing Late Cenozoic Faulting Stress Regimes ${ }^{\mathrm{a}}$

\begin{tabular}{|c|c|c|c|c|c|c|c|c|c|c|c|c|}
\hline \multirow[b]{2}{*}{ Site } & \multirow{2}{*}{$\begin{array}{l}\text { Longitude } \\
\left({ }^{\circ} \mathrm{E}\right)\end{array}$} & \multirow{2}{*}{$\begin{array}{l}\text { Latitude } \\
\left({ }^{\circ} \mathrm{N}\right)\end{array}$} & \multicolumn{2}{|c|}{$\sigma_{1}$} & \multicolumn{2}{|c|}{$\sigma_{2}$} & \multicolumn{2}{|c|}{$\sigma_{3}$} & \multirow[b]{2}{*}{$R$} & \multirow[b]{2}{*}{$N$} & \multirow[b]{2}{*}{ Quality } & \multirow{2}{*}{$\begin{array}{c}\text { Age } \\
\text { (Formation) }\end{array}$} \\
\hline & & & Azim & Dip & Azim & Dip & Azim & Dip & & & & \\
\hline 1 & 58.518 & 36.869 & 10 & 17 & 245 & 63 & 107 & 21 & 0.86 & 18 & A & Quaternary \\
\hline 2 & 58.529 & 36.891 & 30 & 1 & 255 & 89 & 120 & 1 & 0.64 & 8 & B & Pl-Q \\
\hline 3 & 58.513 & 36.824 & 44 & 2 & 141 & 71 & 314 & 18 & 0.88 & 14 & A & Cretaceous \\
\hline 4 & 58.515 & 36.724 & 35 & 11 & 187 & 77 & 303 & 6 & 0.46 & 22 & $\mathrm{~A}$ & Cretaceous \\
\hline 5 & 58.863 & 36.272 & 176 & 11 & 48 & 73 & 268 & 13 & 0.76 & 12 & B & Quaternary \\
\hline 6 & 58.627 & 36.383 & 210 & 1 & 101 & 87 & 300 & 3 & 0.71 & 23 & A & Pl-Q \\
\hline 7 & 57.830 & 36.902 & 25 & 2 & 294 & 22 & 120 & 68 & 0.87 & 19 & A & Quaternary \\
\hline 8 & 57.651 & 36.942 & 208 & 9 & 299 & 8 & 71 & 78 & 0.99 & 17 & A & Quaternary \\
\hline
\end{tabular}

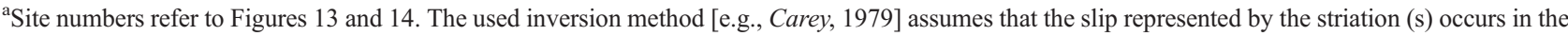
direction of the resolved shear. Deviatoric principal stress axes, $\sigma_{1}, \sigma_{2}, \sigma_{3}$, are the compressional, intermediate and extensional deviatoric axes, respectively. $R=\left(\sigma_{2}-\sigma_{1}\right) /\left(\sigma_{3}-\sigma_{1}\right)$, is the stress ratio of the deviatoric stress tensor, a linear quantity describing relative stress magnitudes. Ages are reported from the geological map cited in text; Azim, azimuth; $N$, number of fault slip pairs considered for stress calculation; quality, A, excellent, $\mathrm{B}$, good.

results and sample treatment procedure are presented in Appendix A.

\subsection{Dating Result}

[27] Sample VOL601 gives a broadly saddle-shaped age spectra with the lowest ages ranging from 2.17 to $2.55 \mathrm{Ma}$ (Table 1 and Figure 12). The fairly strong heterogeneity in the age spectra as well as in the inverse isochron plot suggests excess argon. The low age steps encompass most of the ${ }^{39} \mathrm{Ar}$ released and low chlorine content as shown by the $\mathrm{K} / \mathrm{Ca}$ and $\mathrm{Cl} / \mathrm{K}$ proxy plots. The total fusion age of $3.08 \pm 0.04 \mathrm{Ma}$ is a maximum while a simple average of those low age steps at $2.43 \pm 0.25 \mathrm{Ma}$ is probably close to the correct age.

[28] Sample VOL602 shows a fairly flat age spectra from which a plateau age of $2.34 \pm 0.04 \mathrm{Ma}$ is extracted on more than $80 \%$ of the total ${ }^{39}$ Ar released from the steps with highest $\mathrm{K}$ and lowest chlorine content. The younger total fusion age is dominated by the low ages at the end of the spectra and is non reliable while the isochron yields a slightly older age of $2.64 \pm 0.04 \mathrm{Ma}$ with a MSWD of 4.2 implying scatter above the individual errors. The plateau value is preferred (Figure 12).

[29] Sample VOL603 show a broad saddle-shapes age spectra with only one step of minimum age at ca $2.1 \mathrm{Ma}$ (Figure 12). The total fusion age of $3.98 \pm 0.05 \mathrm{Ma}$ is clearly a maximum and the isochron age of $2.81 \pm 0.08 \mathrm{Ma}$ clearly indicates excess argon $\left({ }^{40} \mathrm{Ar} /{ }^{36} \mathrm{Ar}\right.$ of 461$)$ with a MSWD of 3.5 which suggest that some scatter remains because excess argon has not been completely resolved through the inverse isochron approach. The inverse iso- chron age is taken as the best estimate but probably slightly in excess of the real age.

[30] The three samples gives ages at $2.43 \pm 0.25 \mathrm{Ma}$, $2.34 \pm 0.04 \mathrm{Ma}$ and $2.81 \pm 0.08 \mathrm{Ma}$ (Table 1 and Figure 12), the first two being the most robust and indistinguishable within errors, the third being probably overestimated. This yields a robust estimate for the age of dome intrusion at ca 2.3-2.4 Ma, i.e., ca $2.35 \pm 0.24 \mathrm{Ma}$ when the age uncertainties are considered. The obtained age is used to calculate long-term slip rates along the MTZ strike-slip fault systems (section 7.2).

\section{Modern Stress State in the MTZ Deduced From Fault Kinematics Analyses}

[31] Fault population data consisting of fault planes and associated slip vectors (striations) were measured in eight localities distributed along the boundary faults (Figure 13). Fault kinematic analysis has been performed using a computer program derived from the numerical method of Carey and Brunier [1974] and Carey [1979]. The inversion results include the orientation (azimuth and plunge) of the principal stress axes $\left(\sigma_{1}>\sigma_{2}>\sigma_{3}\right)$ of computed stress tensors as well as the stress ellipsoid shape parameter $\mathrm{R}$, defined as $\mathrm{R}=\left(\sigma_{2}-\sigma_{1}\right) /\left(\sigma_{3}-\sigma_{1}\right)$, which describes relative stress magnitudes ranging from 0 to 1 [see e.g., Carey and Brunier, 1974; Mercier et al., 1991; Bellier and Zoback, 1995, and references therein].

[32] We analyzed the modern state of stress, using the youngest striae sets mostly measured in Plio-Pleistocene conglomerates (Figures 13 and 14 and Tables $2 \mathrm{a}$ and $2 \mathrm{~b}$ ).

Table 2b. Focal Mechanisms Information ${ }^{\mathrm{a}}$

\begin{tabular}{|c|c|c|c|c|c|c|c|c|c|c|c|c|}
\hline \multirow[b]{2}{*}{ Site } & \multirow[b]{2}{*}{ Date } & \multirow{2}{*}{$\begin{array}{l}\text { Longitude } \\
\left({ }^{\circ} \mathrm{E}\right)\end{array}$} & \multirow{2}{*}{$\begin{array}{l}\text { Latitude } \\
\left({ }^{\circ} \mathrm{N}\right)\end{array}$} & \multirow{2}{*}{$\begin{array}{l}\text { Depth } \\
(\mathrm{km})\end{array}$} & \multirow{2}{*}{$\begin{array}{c}\mathrm{M} \\
(\mathrm{mbar})\end{array}$} & \multicolumn{3}{|c|}{ Nodal Plane 1} & \multicolumn{3}{|c|}{ Nodal Plane 2} & \multirow[b]{2}{*}{ Source } \\
\hline & & & & & & Azimuth & Dip & Pitch & Azimuth & Dip & Pitch & \\
\hline 9 & 19690103 & 57.9 & 37.13 & 11 & 5.6 & 132 & $60^{\circ} \mathrm{S}$ & $85^{\circ} \mathrm{W}$ & 142 & $30^{\circ} \mathrm{E}$ & $81^{\circ} \mathrm{N}$ & McKenzie [1972] \\
\hline 10 & 19840706 & 58.33 & 36.56 & 10 & 4.8 & 87 & $64^{\circ} \mathrm{N}$ & $29^{\circ} \mathrm{E}$ & 163 & $64^{\circ} \mathrm{W}$ & $29^{\circ} \mathrm{S}$ & $\begin{array}{l}\text { Mostriouk and } \\
\text { Petrov [1994] }\end{array}$ \\
\hline
\end{tabular}

${ }^{\mathrm{a}}$ Focal mechanisms used for $\mathrm{P}$ axis directions presented in Figure 13. Date (yyyymmdd) follows usual convention and all angles are in degrees. Magnitudes of earthquakes (M) determined using body waves forms. For each focal mechanism, the two nodal planes are characterized by azimuth, dip, and pitch of the inferred motion vector. 


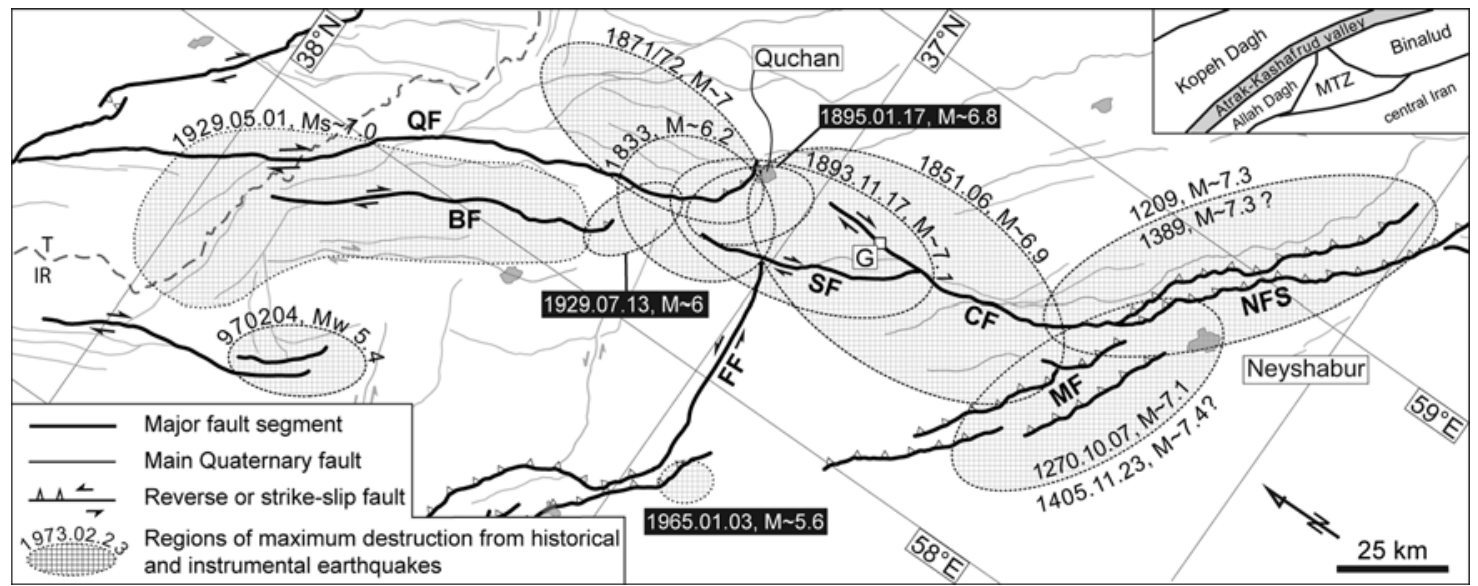

Figure 15. The regions of maximum destruction of earthquakes occurred in NE Iran. The isoseismal regions are based on Ambraseys and Melville [1982], Berberian and Yeats [1999], and Tchalenko [1975]. Only one of the 4 February 1997 Garmkhan earthquakes is from Hollingsworth et al. [2007]. Top right inset is a schematic map of the different deformation domains covered. G, Golmeym village; IR, Iran; T, Turkmenistan; other abbreviations are as in Figure 1.

Separation of distinct families of striations has been done on the basis of geological field data using relative chronology of the striations (crosscutting relationships) and their relationships with regional tectonic events. In all data sets, modern stress state is represented by NNE trending $\sigma_{1}$ ranging from $\mathrm{N} 10^{\circ} \mathrm{E}$ to $\mathrm{N} 50^{\circ} \mathrm{E}$ and shows two distinct (compressional and strike-slip) stress deviators respecting structural setting of the fault slip data (Figures 13 and 14). In this context, the Chakaneh Fault system is characterized by a strike-slip stress regime. Applying the average $\mathrm{N} 25^{\circ} \mathrm{E}$ trending horizontal $\sigma_{1}$ to the geometry of boundary fault systems implies dominant strike-slip faulting along the Chakaneh and Farhadan fault systems, together with the Sar'akhor Fault. Considering the fault orientations, the Chakaneh Fault system and the Sar'akhor Fault are characterized by right-lateral and the Farhadan Fault system is characterized by left-lateral motions. The inversion results of the fault slip data are presented in Table $2 \mathrm{a}$ and $2 \mathrm{~b}$.

[33] The correlation between the youngest geomorphic expression of the inspected faults and relative chronology of the fault striations, suggests that the computed stress deviators (average $\mathrm{N} 25^{\circ} \mathrm{E}$ trending $\sigma_{1}$ ) can confidently characterized the present-day stress state in the MTZ. This is consistent with the NE trending mean $\mathrm{P}$ axis deduced from focal mechanisms of the rare earthquakes $(5 \geq M \geq 7)$ that occurred in the region (Figure 13), as well as the average regional $\mathrm{N} 32^{\circ} \mathrm{E}$ trending $\sigma_{1}$ stress axis computed from focal mechanisms inversion of moderate to large earthquakes in northeast Iran [Zamani et al., 2008].

\section{Summary and Discussion}

[34] As presented above, major fault segments in the MTZ have been mapped at the regional scale, with the objective to recognize their structural and geomorphic characteristics. At the site scale, analyses of SPOT 5 images combined with direct field observations were used to quantify cumulative offsets along the newly recognized active faults. In this context, the Chakaneh and Farhadan fault systems and the Sar'akhor Fault were characterized (section 3) as the principal right-lateral (Chakaneh Fault system and Sar'akhor Fault), and left-lateral (Farhadan Fault system) strike-slip structures in the MTZ. Our geological and geomorphic investigations reveal large cumulative lateral offsets $(5-8 \mathrm{~km})$ along the Farhadan and Chakaneh fault systems. The same offset amounts recorded by the Eocene and Pliocene geological units indicate that strike-slip faulting should not be starting before Pliocene. All together, the presented results in this paper provide evidence for considerable strike slip faulting through the MTZ since $\sim 5 \mathrm{Ma}$ ago. The triangular arrangement of the MTZ boundary fault systems appears to be a selective combination of predominant fault trends of the Alborz, Kopeh Dagh and central Iran. Indeed, the Farhadan and Meshkan fault systems were limited or even offset by NNW trending right-lateral faults, i.e., the Chakaneh Fault system and Sar'akhor Fault. This crosscutting relationship is consistent with the major role of right-lateral faults within the structural pattern emplacement that is transferring part of the northward motion of central Iran to the Kopeh Dagh. The Modern state of stress (section 6) is also in agreement with active strike-slip faulting along the Farhadan (left-lateral) and Chakaneh (right-lateral) fault systems and reverse faulting along the Meshkan Fault system at the boundaries of the MTZ.

\subsection{Reassessment of the Historical Seismicity Pattern in NE Iran}

[35] A long and detailed historical record of earthquakes in northeastern Iran spans over the last 900 years [Tchalenko, 1975; Ambraseys and Melville, 1982; Berberian and Yeats, 1999; Berberian and Yeats, 2001]. In the Kopeh Dagh and Binalud mountain ranges, the relationship between seismicity and preexisting faults has already been discussed [Tchalenko, 1975; Ambraseys and Melville, 1982; Berberian and Yeats, 1999; Berberian and Yeats, 2001]. 
Since the 12th century, NE Iran (Kopeh Dagh and Binalud) has experienced at least 12 large earthquakes, which, with magnitudes ranging from 6.5 to 7.5 , almost all of them occurred in the vicinity of the major fault zones (Figure 15). These large earthquakes (Baghan earthquake 1929; Quchan earthquakes 1851(?), 1871-72, 1893(?), 1895; Neyshabur earthquakes $1209,1270,1389,1405)$ were directly assigned to the significant structures of the region such as the Baghan, Quchan and Neyshabur faults [Tchalenko, 1975; Ambraseys and Melville, 1982; Berberian and Yeats, 1999; Berberian and Yeats, 2001]. However, the band of maximum destruction associated to these historical earthquakes appears to follow the trends of Quchan and Baghan faults connecting to the Neyshabur Fault system. Among the earthquakes assigned to the Quchan fault [Tchalenko, 1975; Ambraseys and Melville, 1982], the macroseismic regions associated to two earthquakes do not certainly correspond with the Quchan Fault trace (1851 and 1893 earthquakes). Noteworthy, such assignments were only based on the facts that the Quchan Fault is the major strike-slip fault in the region, and that there was no data indicating the active faulting through the macroseismic areas, i.e., the MTZ. The documented faults in this paper give therefore new insights to reinterpret this historical seismicity. According to our data and observations, the Chakaneh Fault system and Sar'akhor Fault are the only main active faults in the maximum destruction regions of 1851 and 1893 earthquakes. Indeed, the fault traces correspond well to the well-defined extent of the maximum destruction regions (Figure 15). In such a case, the most reliable possibility is that the Chakaneh Fault system and Sar'akhor Fault have been reactivated during the respective 1851 and 1893 earthquakes. However, there is no evidence for coseismic rupture along the Chakaneh Fault system, associated to the 1851 earthquake [Tchalenko, 1975; Ambraseys and Melville, 1982]. Nevertheless, our discussions with old villagers from Golmeym village revealed a sudden shut in discharge of the Golmeym spring (along the fault trace) as coseismic phenomenon during 1851 earthquake. Our interpretation implies, except two potentially related earthquakes $(1833,1895)$, that no macroseismic region can be directly assigned to the Quchan Fault (Figure 15). More precisely, there is no documented historical or instrumental seismicity along the most important active strike-slip fault of the Kopeh Dagh [e.g., Shabanian et al., 2009]. This fact brings into question the seismic behavior of the Quchan Fault and the recurrence interval of the large earthquakes in the Kopeh Dagh.

\subsection{Long-Term Strike-Slip Rates in the MTZ}

[36] In this study, the slip rate estimates are based on the assumption that the fault slip rates remained constant since formation of the offset markers. Because the used time spans to evaluate the rates are large enough (2.5 to $5 \mathrm{Ma})$, the proposed slip rates are valid if no significant tectonic change has occurred during that period of time.

[37] For the Chakaneh Fault system, the measured cumulative offset of $1900 \pm 50 \mathrm{~m}$ through the volcanic dome (section 4.1) is dated at maximum ca $2.35 \pm 0.24 \mathrm{Ma}$ (i.e., post dating the age of the dome intrusion). The obtained values yield an average slip rate of $0.8 \pm 0.1 \mathrm{~mm} / \mathrm{a}$ along the Golmeym Fault (northern segment). For its southern segment (Dâmanjan Fault), a minimum slip rate of about $1.2 \mathrm{~mm} / \mathrm{a}$ can be deduced considering the total cumulative fault offset of $5.8 \pm 0.8 \mathrm{~km}$ (Figure 4) and the suggested maximum inception date of $\sim 5$ Ma for the initiation of right-lateral strike-slip faulting in the MTZ (sections 3.1 and 3.2). This is slightly higher than that calculated for the Golmeym Fault $(0.8 \pm 0.1 \mathrm{~mm} / \mathrm{a})$. Considering the fact that the offset volcanic dome is located near the northern fault termination (Figures 3 and 10), the Golmeym Fault slip rate can be regarded as a lower bound since cumulative fault displacements decrease northward along the Chakaneh Fault system (section 4).

[38] Along the Farhadan Fault, the post-Pliocene ( $\sim 5 \mathrm{Ma})$ cumulative offset of $7.3 \pm 0.8 \mathrm{~km}$ (Figure 5) yields a minimum long-term slip rate of $1.4 \pm 0.1 \mathrm{~mm} / \mathrm{a}$. On the other hand, the geomorphic left-lateral offset of $5.6 \pm 0.2 \mathrm{~km}$ (Figure 6), presented by the oldest drainages incised in pyroclastic terrains, predates the last volcanic extrusion at ca $2.35 \pm 0.24 \mathrm{Ma}$ (section 5). This allows limiting the upper bound of the Farhadan Fault slip rate at maximum of $2.3 \pm 0.5 \mathrm{~mm} / \mathrm{a}$, and deducing a constrained long-term slip rate of $1.8 \pm 0.4 \mathrm{~mm} / \mathrm{a}$.

[39] The Sar'akhor Fault exhibits a cumulative rightlateral offset of $2.7 \pm 0.3 \mathrm{~km}$ (Figure 7), displacing PlioQuaternary lavas. Even if the lavas age in unclear, the last volcanic episode at ca $2.35 \pm 0.24$ Ma ago (domes intrusion), defines a minimum age limit for it. Accepting this assumption, a maximum lateral slip rate of $1.1 \pm 0.2 \mathrm{~mm} / \mathrm{a}$ is estimated for the Sar'akhor Fault.

\subsection{Strike-Slip Faulting Between the Binalud and Kopeh Dagh Mountains}

[40] The possibility of a structural linkage between the Kopeh Dagh and Binalud mountain ranges has already been evaluated in previous studies [Tchalenko, 1975; Afshar Harb, 1979; Hollingsworth et al., 2006]. Despite the lack of clear structural linkage between the Kopeh Dagh and Binalud mountain ranges, the pioneer work by Tchalenko [1975] suggested a possible connection between the two deformation domains. Conversely, the lack of knowledge about strike-slip faulting in the MTZ led Hollingsworth et al. [2006] to conclude that the strike-slip faulting within the Kopeh Dagh is not transferred southward beyond the Atrak valley. On the other hand, the GPS-derived rate of 2-4 $\mathrm{mm} / \mathrm{a}$ for range parallel displacement through the Binalud Mountains [Masson et al., 2007; Tavakoli, 2007] implies significant right-lateral strike-slip faulting along both sides of the mountains (i.e., the Mashhad and/or Neyshabur fault systems; Figure 16). Such a configuration could not be explained by the known structural pattern in NE Iran. As an important result, the data presented in this study uncovered evidence for clear structural linkage between the Kopeh Dagh and Binalud mountains. This leads us to propose a new consistent tectonic pattern for NE Iran in which, part of motion of central Iran with respect to Eurasia $(\sim 2 \mathrm{~mm} / \mathrm{a})$ is transferred northward from the Binalud to the Kopeh Dagh Mountains through 


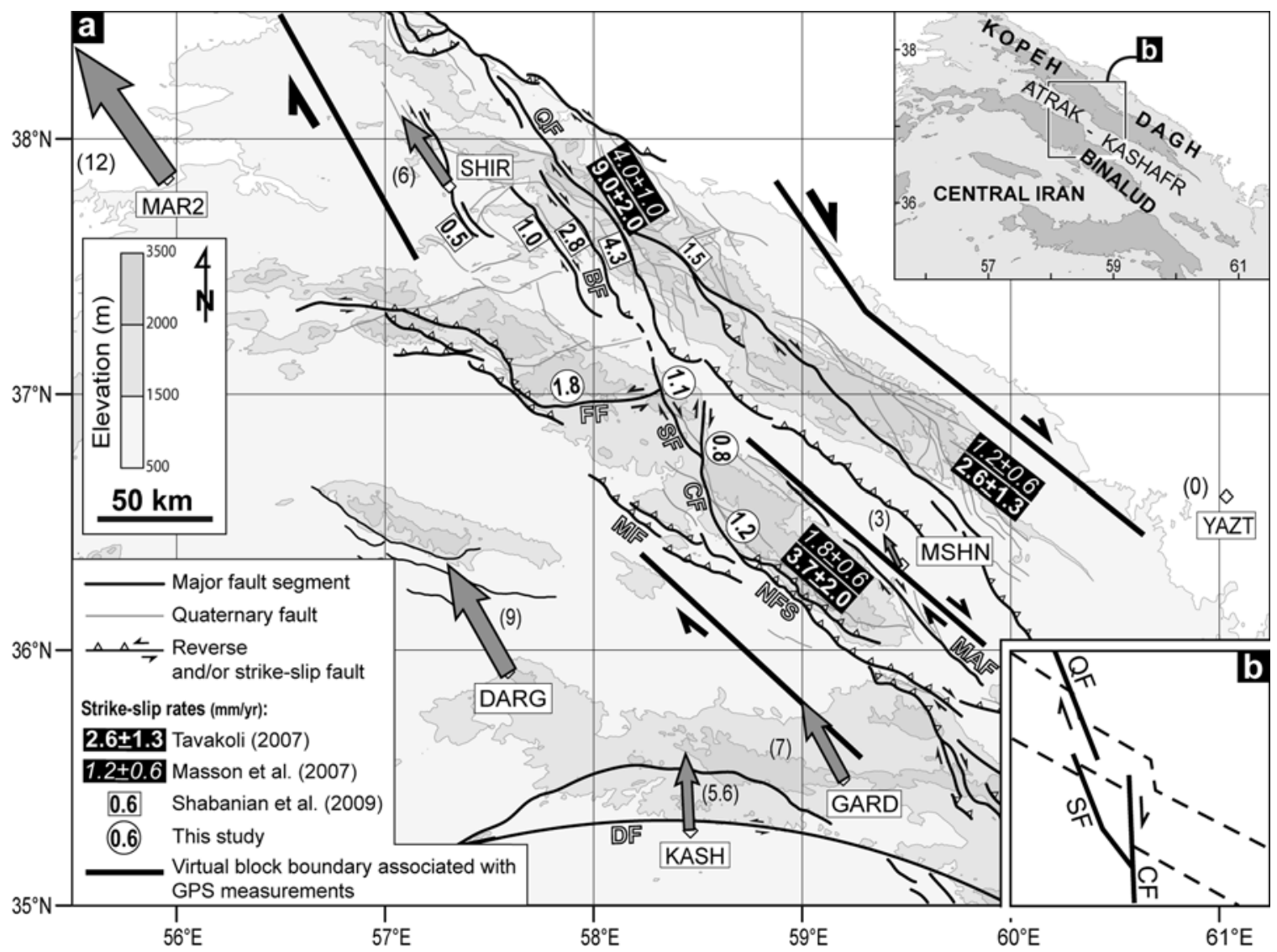

Figure 16. (a) Simplified active fault map (based on the work by Shabanian et al. [2009] and this study) of NE Iran showing location of the MTZ in the geodynamic context of the northeastern ArabiaEurasia collision. Gray arrows and their associated numbers are GPS horizontal velocities in a Eurasiafixed reference frame (YAZT station) expressed in $\mathrm{mm} / \mathrm{a}$ [Tavakoli, 2007]. The inset shows different mountain ranges and structural domains mentioned in the text as well as the Atrak-Kashafrud valley in the same frame as Figure 16a. (b) Simplified map centered on the Kopeh Dagh-Meshkan faults relay zone showing the affected morphology of the Atrak-Kashafrud valley by the named faults.

the MTZ strike-slip faults (Figure 16). In this context, the Farhadan Fault is considered as the easternmost extension of left-lateral strike-slip faulting within the Kopeh Dagh and the eastern Alborz [e.g., Jackson et al., 2002] favoring the northwestward motion of the western Kopeh Dagh with respect to its eastern part.

[41] In the Atrak valley, there is no direct geomorphic or geological evidence for the structural linkage between the Kopeh Dagh fault systems and the MTZ fault systems. However, the particular situation of the Atrak valley (e.g., the long-time human settlement and cultivation) would likely removes possible fault surface expressions. Nonetheless, according to our observations, we cannot rule out that the fault systems dissected or at least, affected the valley because (1) an apparent right-lateral cumulative offset of $\sim 12 \mathrm{~km}$ can be deduced analyzing the topography of the Atrak valley (Figure 16), (2) the band of maximum destruction (macroseismic regions) associated to the historical earthquakes in NE Iran (Figure 15), follows the trends of the Quchan and Baghan faults joining the Neyshabur Fault system through the Chakaneh Fault system and the Sar'akhor Fault (section 7.1). In this context, at least two macro- seismic regions (1895 and 1929 earthquakes) are observed within the Atrak valley having different orientations and locations with respect to the mapped thrust-bend fault terminations proposed by Hollingsworth et al. [2006], and (3) the observed geomorphic offset along the inferred trace of the Sar'akhor Fault within the valley (Figure 9) implies that the fault runs northward through the Atrak valley joining to the Baghan Fault. All together, these observations indicate that the strike-slip faulting within the Kopeh Dagh does not die out at the northern part of the valley. In other words, the area between the Kopeh Dagh and MTZ fault systems, including the Atrak-Kashafrud valley and thrust-bend terminations (Figures 15 and 16), should be considered as a relay zone between the two fault systems. This, in turn, explains the right-lateral offset of the valley and the occurrence of several large earthquakes $(M>6)$ in this area.

\subsection{Kinematics of Continental Deformation in NE Iran}

[42] NE Iran, including the Kopeh Dagh and Allah Dagh-Binalud mountains, is involved in oblique convergence at the northeastern boundary of the Arabia-Eurasia 


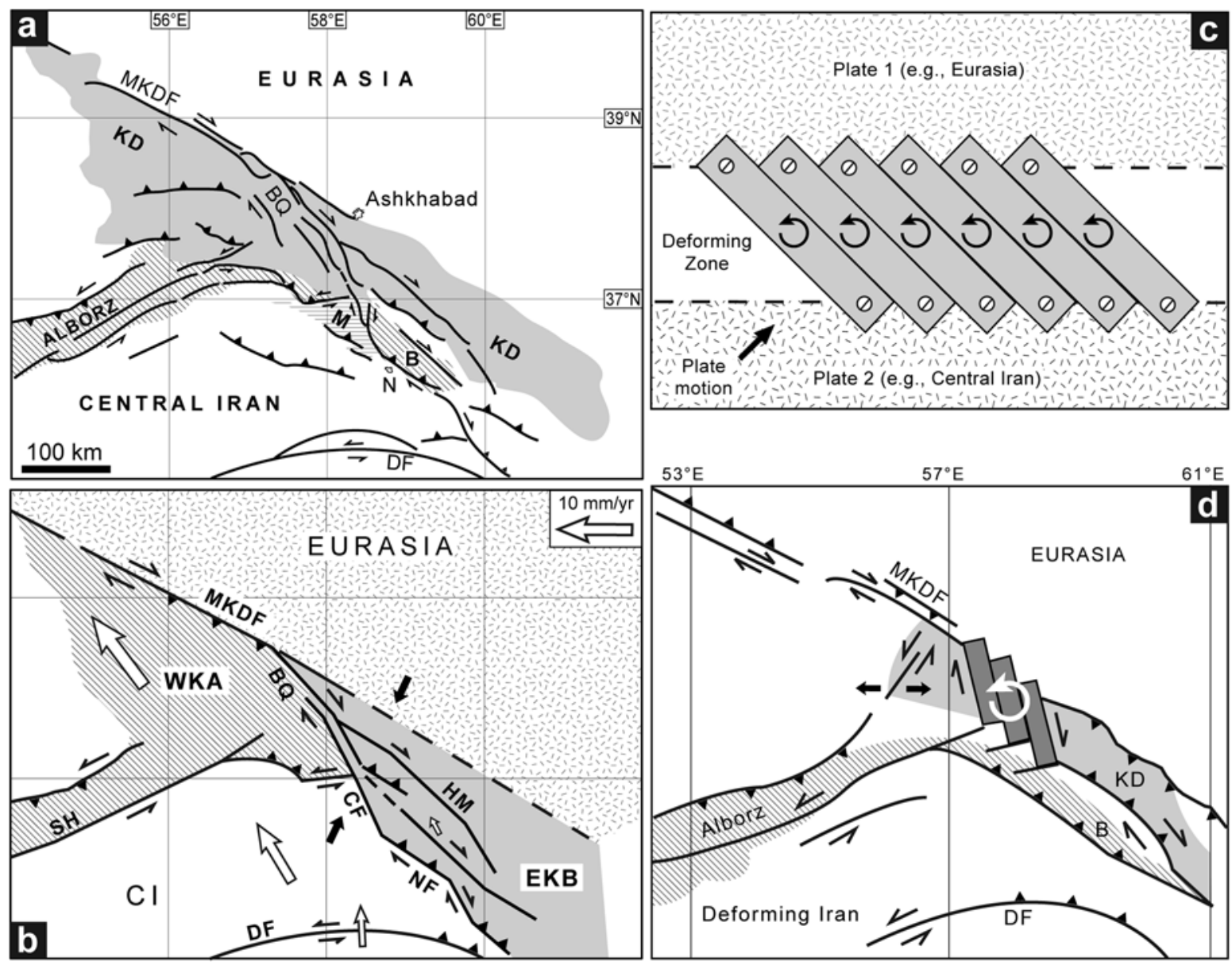

Figure 17. (a) Simplified active fault map together with the main tectonic domains of NE Iran. M, Meshkan Transfer Zone; B, Binalud; N, Neyshabur. (b) Schematic kinematic model showing the new tectonic configuration in NE Iran based on the data and results presented in this paper. WKA, western Kopeh Dagh-Alborz tectonic domain; EKB, eastern Kopeh Dagh-Binalud tectonic domain; SH, Shahrud Fault system; HM, Hezar Masjed Fault system; other abbreviations are as in Figure 1. White arrows are the same GPS velocity vectors than that Figure 16. Black arrows show the direction of the $\sigma_{1}$ stress axis (see Figure 13). The inactive NE margin of the Kopeh Dagh is marked by dashed line. (c) The "pinned block model" modified after McKenzie and Jackson [1986]; the fault bounded blocks are pinned on the stable plates in either side. (d) Simplified version of the kinematic model proposed by Hollingsworth et al. [2008].

collision. The Kopeh Dagh Mountains form a NW trending active deformation belt that separates central Iran from Eurasia (Turan platform) (Figure 1). Mesozoic and Tertiary sediments of the Kopeh Dagh were folded into parallel, asymmetric NW trending folds during the Oligo-Miocene orogenic movements [Stöcklin, 1968; Afshar Harb, 1979; Lyberis and Manby, 1999]. These folds are obliquely dissected by strike-slip fault systems that consist of active NNW trending right-lateral and ENE trending left-lateral strike-slip faults [e.g., Tchalenko, 1975; Afshar Harb, 1979; Shabanian et al., 2009] extended within the western and central Kopeh Dagh. The Allah Dagh-Binalud Mountains (Figure 1) form NW trending Mesozoic paleoreliefs south of the Kopeh Dagh that thrusts over the northern margin of central Iran. Conversely to the Kopeh Dagh, tectonic evolution of the Binalud is much more complex. A collection of the paleo-Tethys remnants as well as lower Paleozoic, middle and upper Mesozoic, and Cenozoic rocks has been submitted to successive major ductile or brittle tectonic deformation episodes since the paleo-Tethys closure (pre-late Triassic) [Alavi, 1992]. However, the Cenozoic tectonics is roughly identical for the entire region.

[43] Late Cenozoic faulting and the accommodation mode of deformations in northeast Iran was already discussed by Tchalenko [1975], Lyberis and Manby [1999], Jackson et al. [2002], Hollingsworth et al. [2006, 2008], Shabanian et al. [2009], and Siame et al. [2009]. The first kinematics model for NE Iran was proposed by McKenzie 
and Jackson [1983, 1986]. They claimed that continuum mechanisms can appropriately describe the instantaneous deformation in NE Iran. In this context the Kopeh Dagh was considered as an excellent example that exhibits the characteristic features of their "pinned model" by distributed deformation (Figure 17). According to this model, the overall motion in the Kopeh Dagh is expressed by large blocks bounded by the throughgoing faults that rotate about two pivot points, one on each plate, that is, Eurasia in the north and central Iran in the south. Strike-slip fault motions are accompanied by a component of thrust faulting. On the basis of the same model, Jackson et al. [2002] expected that the strike-slip faulting within the Kopeh Dagh, which strikes NNW at an oblique angle to the belt, rotates anticlockwise about a vertical axis as the deformation progresses to eventually become parallel to the regional strike [see also Jackson and McKenzie, 1984; Jackson et al., 1995]. Subsequently, this hypothesis has become a dogma to explain kinematics of deformations in the Kopeh Dagh [Hollingsworth et al., 2006, 2008]. Hollingsworth et al. [2006] proposed a nearly similar block rotation model to explain the total right-lateral cumulative offset of 35-40 km along the Bakharden-Quchan Fault system as the apparent offsets due to anticlockwise rotation of fault-bounded blocks around vertical axes (Figure 17). According to this model, northward motion of central Iran was thought to be accommodated between the Turan platform and central Iran involving (1) dominant thrust faulting at the southern boundaries of the Kopeh Dagh (north of the Atrak-Kashafrud valley), without significant strike-slip faulting and (2) anticlockwise block rotation around a vertical axis within the Kopeh Dagh [see also Jackson et al., 2002]. All the hypotheses mentioned above are based on the idealized continuum model proposed by McKenzie and Jackson [1983, 1986] to explain the relationship between finite strain and fault movements within a deforming zone submitted to the oblique convergence or divergence. The fundamental assumptions of such models are that (1) the deformation is uniformly distributed over the deforming zone, i.e., the homogeneous deformation, and (2) the rigid boundaries of the deforming zone remain constant during the deformation process. In this view, the throughgoing strike-slip faults, oblique to the strike of the zone, are passive structures confined within the zone boundaries. Consequently, observed deformation on these faults is controlled by kinematic constraints associated with the finite deformation.

[44] Recently, quantitative geological and geomorphic investigations by Shabanian et al. [2009] provided the first geological constraints on the late Cenozoic faulting in the Kopeh Dagh. Examining distribution of postfolding brittle deformation using satellite imagery, SRTM data, and field observations, Shabanian et al. [2009] show that (1) the strike-slip brittle deformation is not uniformly distributed within the Kopeh Dagh but that it is focalized on a welldefined intracontinental strike-slip fault system (BQFS) which obliquely dissects the belt, and (2) there is no structural evidence supporting regional anticlockwise block rotation within the central eastern Kopeh Dagh. In this paper, we show that a significant part $(\geq 25 \%)$ of the late
Cenozoic brittle deformation within the Kopeh Dagh is taken up by prominent strike-slip faulting through the MTZ being transferred to the Binalud Mountains. Such a mechanism strongly favors a simple strike-slip faulting mechanism that translates the central Iran northward relative to the east. Moreover, it implies that the original range-parallel boundaries of both the Kopeh Dagh and Binalud deformation domains was affected by the late Cenozoic strike-slip faulting focalized on few NNW striking structures (Figure 17). All together, the geologically derived results reveal that the distribution pattern of deformation is easily described as the focalized deformation along major block bounding strike-slip faults in NE Iran where previous authors [McKenzie and Jackson, 1983, 1986; Hollingsworth et al., 2006, 2008] predict several rotating "slats" (Figure 17). With the great benefit of quantitative geological observation we see their model as more complex than is necessary to explain the large-scale kinematics. However, our data and observation propose a simpler model in which central Iran and the western Kopeh Dagh are translated northward with respect to Eurasia by focalized intracontinental strike-slip faulting (Figure 17). It is noteworthy that, in an oblique convergence, an along-strike elongation of the deforming zones can occur due to the obliquity of the strike-slip faults with respect to the zone boundaries. Therefore, in the case of the Kopeh Dagh and Binalud, a NW elongation results from right-lateral fault motions along the NNW trending strike-slip faults (Figure 17). Such a mechanism simply explains material translation in the western Kopeh Dagh toward the South Caspian Basin, taken up by lateral motion on the Main Kopeh Dagh Fault and the Shahrud Fault system. In summary, our data and deduced results do not support the fundamental assumptions for the popular hypothesis of distributed deformation proposed by McKenzie and Jackson [1983], and subsequently followed by Jackson and McKenzie [1984], Jackson et al. [1995], Jackson et al. [2002], and Hollingsworth et al. [2006, 2008].

[45] The new tectonic configuration presented here is also consistent with the GPS-derived velocity field [Tavakoli, 2007] in NE Iran (Figures 1 and 16). All the stations west of the right-lateral strike-slip fault systems (i.e., BQFS and Chakaneh Fault system) move northwest with respect to YAZT station in the eastern side (Eurasia). Their relative overall motion is nearly parallel to the regional strike (NNW) of the fault systems. This suggests a clear northwestward translation of the western side along the rightlateral strike-slip faults, which are considered as the present-day active boundary between Iran and Eurasia. Since major strike-slip faults slip under very low resolved shear stress [e.g., Mount and Suppe, 1987; Zoback et al., 1987], these faults can slip in a direction that is not parallel to the relative motion of the microplates or plates they bound. In such a case, the GPS velocity field indicates a direction different from the both directions of convergence and maximum compressional stress axis $\left(\sigma_{1}\right)$.

[46] In the MTZ, the GPS velocity field can also explain the fault kinematics observed on the ENE striking leftlateral faults such as the Farhadan Fault system. Comparing 
the GPS velocity vectors from GARD and DARG with MAR2 stations, one can estimate a westward motion rate of 3 to $5 \mathrm{~mm} / \mathrm{a}$ for the eastern Alborz and the western Kopeh Dagh with respect to central Iran. This relative motion is taken up on ENE striking left-lateral faults at the southern boundary of the eastern Alborz and the western Kopeh Dagh.

\subsection{Changes in Original Boundaries of Deforming Zones}

[47] Plate boundary and internal driving forces can change with time, both abruptly and in small increments, leading to deactivation and migration of deforming zones. Active tectonic and magmatic processes also alter both applied forces and rheology, which encourage the temporal migration of patterns of deformation. Each force increment changes the intraplate stress field, altering the shearing and normal stresses across active faults and inactive potential failure planes. The magnitude of the effect depends upon the force increment and the preexisting stress field, either encouraging or discouraging fault slip [Thatcher, 2003]. As it was suggested by Zoback and Townend [2001], if the crust is almost everywhere stressed very near to a state of frictional fault failure, then small stress increments could significantly alter preexisting deformation patterns. On the other hand, as a result of the buoyancy of continental crust, zones of preexisting weakness (mechanical anisotropy in the lithosphere) are effectively "locked-in" to the continents and can potentially be reactivated many times during successive phases of continental deformation and accretion episodes [e.g., Thatcher, 1995; Storti et al., 2003, and references therein]. Therefore, it may be expected that major tectonic reorganizations lead to significant structural rearrangements and changes in boundary conditions (forces and geometry) of old deformation belts. Hence, it is important to investigate present-day tectonic configurations in actively deforming zones before describing kinematics of deformation. For instance, all attempts to describe the kinematics of deformation in NE Iran have been based on paleotectonic knowledge of this region [e.g., McKenzie and Jackson, 1983; Hollingsworth et al., 2006].

[48] In NE Iran, pre-Pliocene shortening perpendicular to the range was expressed in range-parallel folding in the Kopeh Dagh [Afshar Harb, 1979; Lyberis and Manby, 1999], thrust faulting at the southern side of the Binalud Mountains [Alavi, 1992], and folding as well as thrust faulting in the MTZ (this study). It seems that each deformation domain has its own characteristic deformation. Conversely, post-Miocene deformation is characterized by prominent strike-slip faulting on nearly vertical faults [Shabanian et al., 2009; this study] oblique to the ranges. These faults dissect and offset the range-parallel fold axes and thrust faults throughout the region. In this context, the major right-lateral strike-slip faults cut through the Kopeh Dagh and Binalud deformation domains creating new boundaries for the deforming zones. This scenario implies major structural rearrangements in NE Iran that is accompanied with major kinematics and geometric evolutions in the northeastern Arabia-Eurasia collision zone (Figure 17).

[49] Within this context, the post-Miocene tectonic reorganization (3-5 Ma [Shabanian et al., 2009; this study]) not only caused regional strike-slip faulting in NE Iran but also caused a drastic change in the old boundaries of the Kopeh Dagh and Binalud deformation domains and has an important implication for the evolution of active convergences.

[50] It is suggested that continued convergence will manifest itself by a growth in area of the range or plateau, as thrust faulting leads to crustal thickening on its margins [Molnar, 1988]. Nonetheless, it seems that this condition cannot be attributed to all active convergences. At least in NE Iran, the deformation pattern and thickening processes within actively deforming mountain belts has been strongly affected by late Cenozoic tectonic reorganization in the belts. This tectonic reorganization and the consequent structural rearrangement reactivated inherited faults, cutting the boundaries of the old deformation zones and to create a new tectonic configuration (Figure 17) more consistent with the new tectonic regime. The newly created boundaries take up more easily active deformation between converging plates. Such a deformation pattern does not need to grow in area of the range by thrusting in respond to continued convergence.

[51] From a geodynamic perspective, there is perhaps an agreement that a significant change occurred in the nature of the Arabia-Eurasia collision zone at $5 \pm 2 \mathrm{Ma}$ [e.g., Hempton, 1987; Westaway, 1994; Axen et al., 2001; Allen et al., 2004; Copley and Jackson, 2006], though the cause for this change is debated. The widely accepted suggestions for the cause of this change include the arrival of buoyant Arabian continental crust choking the Neo-Tethyan subduction zone [Axen et al., 2001], possible initiation of westward escape of the Anatolian Platelet between the North and East Anatolian faults [Westaway, 1994; Koçyigit et al., 2001], slab break-off in the Bitlis-Zagros collision belt [Authemayou et al., 2006, 2009; Faccenna et al., 2006], and uplift of the Turkish-Iranian Plateau and a migration of deformation to its edges due to a dynamically supported increase in crustal thickening [Allen et al., 2002, 2004] or elevation [Copley and Jackson., 2006]. However, considering the contemporaneity of this widespread drastic reorganization, we suggest that the occurrence of relatively synchronous tectonic events $(5 \pm 2 \mathrm{Ma})$ within different deformation domains throughout the Middle East cannot be entirely explained by only a single cause among those mentioned above. For instance, in regions such as the Kopeh Dagh, there is no evidence for migration of deformation outward of the previously deformed belt [Allen et al., 2004; Copley and Jackson, 2006], where pre-Pliocene compressive tectonic regime was replaced by present-day strike-slip one. Similar scenarios were also reported for the Makran-Zagros transition zone [Regard et al., 2004, 2005] and the Lesser Caucasus [Koçyigit et al., 2001]. On the other hand, because of the 10 Ma sampling interval in the model proposed by McQuarrie et al. [2003], we cannot rule out the possibility of changes in plate's behavior and dynamics of the ArabiaEurasia convergence during the last $10 \mathrm{Ma}$. In this case, we do not really know if the Pliocene tectonic reorganization is a consequence of possible changes in dynamics of the African-Arabian plates, or due to rearrangement of 
Table A1. The ${ }^{40} \mathrm{Ar} /{ }^{39} \mathrm{Ar}$ Analytical Data ${ }^{\mathrm{a}}$

\begin{tabular}{|c|c|c|c|c|c|c|c|c|c|c|}
\hline Temperature $\left({ }^{\circ} \mathrm{C}\right)$ & ${ }^{40} \mathrm{Ar} /{ }^{39} \mathrm{Ar}$ & ${ }^{38} \mathrm{Ar} /{ }^{39} \mathrm{Ar}$ & ${ }^{37} \mathrm{Ar} /{ }^{39} \mathrm{Ar}$ & $\begin{array}{c}{ }^{36} \mathrm{Ar} /{ }^{39} \mathrm{Ar} \\
\left(10^{-3}\right)\end{array}$ & 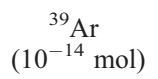 & $\begin{array}{l}\mathrm{F}^{39} \mathrm{Ar} \\
\text { Released }\end{array}$ & $\%{ }^{40} \mathrm{Ar}^{*}$ & ${ }^{40} \mathrm{Ar} *{ }^{39} \mathrm{Ar}$ & $\begin{array}{l}\text { Age } \\
\text { (Ma) }\end{array}$ & $\begin{array}{l} \pm 1 \sigma \\
\text { (Ma) }\end{array}$ \\
\hline \multicolumn{11}{|c|}{ Sample VOL601 } \\
\hline 300 & 39.390 & 0.117 & 0.925 & 130.791 & 0.21 & 0.41 & 1.97 & 0.78 & 12.67 & 4.29 \\
\hline 400 & 6.831 & 0.044 & 0.438 & 20.098 & 0.29 & 0.97 & 13.16 & 0.90 & 14.64 & 0.97 \\
\hline 500 & 1.006 & 0.016 & 0.274 & 2.324 & 1.08 & 3.09 & 31.41 & 0.32 & 5.16 & 0.24 \\
\hline 600 & 0.399 & 0.013 & 0.302 & 0.603 & 5.25 & 13.44 & 54.96 & 0.22 & 3.59 & 0.05 \\
\hline 650 & 0.274 & 0.013 & 0.332 & 0.396 & 8.24 & 29.68 & 57.28 & 0.16 & 2.56 & 0.03 \\
\hline 700 & 0.208 & 0.013 & 0.363 & 0.181 & 10.43 & 50.22 & 75.20 & 0.16 & 2.55 & 0.02 \\
\hline 750 & 0.215 & 0.014 & 0.427 & 0.187 & 10.54 & 70.98 & 77.02 & 0.17 & 2.70 & 0.02 \\
\hline 800 & 0.188 & 0.014 & 0.546 & 0.229 & 7.58 & 85.91 & 70.93 & 0.13 & 2.18 & 0.03 \\
\hline 850 & 0.225 & 0.015 & 0.807 & 0.410 & 3.70 & 93.18 & 59.01 & 0.13 & 2.17 & 0.05 \\
\hline 900 & 0.346 & 0.019 & 1.314 & 0.611 & 1.39 & 95.92 & 65.03 & 0.22 & 3.68 & 0.11 \\
\hline 950 & 0.559 & 0.033 & 2.032 & 1.211 & 0.63 & 97.16 & 54.45 & 0.30 & 4.98 & 0.23 \\
\hline 1000 & 0.846 & 0.057 & 3.200 & 0.906 & 0.42 & 97.98 & 88.89 & 0.75 & 12.28 & 0.25 \\
\hline 1050 & 1.017 & 0.090 & 5.281 & 3.118 & 0.36 & 98.68 & 38.86 & 0.40 & 6.47 & 0.52 \\
\hline 1100 & 2.097 & 0.094 & 10.625 & 7.407 & 0.22 & 99.10 & 25.37 & 0.54 & 8.74 & 0.91 \\
\hline 1150 & 4.768 & 0.084 & 11.704 & 16.237 & 0.21 & 99.52 & 13.82 & 0.66 & 10.83 & 1.27 \\
\hline 1200 & 15.717 & 0.113 & 8.948 & 50.048 & 0.14 & 99.80 & 9.22 & 1.46 & 23.69 & 2.33 \\
\hline \multicolumn{11}{|c|}{ Sample VOL602 } \\
\hline 300 & 20.361 & 0.060 & 0.563 & 70.287 & 0.28 & 0.53 & -1.94 & -0.39 & 0.00 & 0.00 \\
\hline 400 & 5.614 & 0.029 & 0.462 & 18.220 & 0.39 & 1.25 & 4.23 & 0.24 & 3.88 & 0.76 \\
\hline 500 & 0.905 & 0.015 & 0.284 & 2.601 & 1.34 & 3.75 & 14.77 & 0.13 & 2.19 & 0.47 \\
\hline 600 & 0.691 & 0.013 & 0.334 & 1.847 & 5.13 & 13.34 & 21.06 & 0.15 & 2.38 & 0.06 \\
\hline 600 & 0.712 & 0.013 & 0.334 & 1.887 & 5.11 & 22.90 & 21.75 & 0.15 & 2.53 & 0.07 \\
\hline 650 & 0.613 & 0.013 & 0.396 & 1.610 & 8.12 & 38.07 & 22.99 & 0.14 & 2.30 & 0.05 \\
\hline 700 & 0.222 & 0.013 & 0.348 & 0.265 & 10.53 & 57.76 & 65.14 & 0.14 & 2.36 & 0.03 \\
\hline 750 & 0.225 & 0.014 & 0.464 & 0.316 & 9.36 & 75.26 & 62.04 & 0.14 & 2.28 & 0.03 \\
\hline 800 & 0.224 & 0.015 & 0.739 & 0.355 & 5.84 & 86.18 & 64.13 & 0.14 & 2.35 & 0.04 \\
\hline 850 & 0.276 & 0.017 & 1.273 & 0.853 & 2.71 & 91.24 & 29.45 & 0.08 & 1.33 & 0.09 \\
\hline 900 & 0.429 & 0.021 & 1.899 & 1.361 & 1.34 & 93.75 & 28.31 & 0.12 & 1.99 & 0.16 \\
\hline 950 & 0.590 & 0.030 & 2.276 & 1.830 & 0.93 & 95.49 & 28.24 & 0.17 & 2.73 & 0.24 \\
\hline 1000 & 0.727 & 0.040 & 2.769 & 2.658 & 0.71 & 96.82 & 12.26 & 0.09 & 1.46 & 0.36 \\
\hline 1050 & 2.842 & 0.063 & 2.832 & 10.097 & 0.66 & 98.06 & 0.34 & 0.01 & 0.16 & 0.50 \\
\hline 1100 & 32.292 & 0.117 & 4.562 & 112.203 & 0.41 & 98.83 & -1.88 & -0.61 & 0.00 & 0.00 \\
\hline 1150 & 74.016 & 0.195 & 6.245 & 257.272 & 0.31 & 99.40 & -2.23 & -1.66 & 0.00 & 0.00 \\
\hline 1200 & 157.979 & 0.169 & 3.674 & 547.022 & 0.19 & 99.75 & -2.19 & -3.47 & 0.00 & 0.00 \\
\hline \multicolumn{11}{|c|}{ Sample VOL603 } \\
\hline 300 & 23.592 & 0.063 & 0.765 & 79.007 & 0.18 & 0.48 & 1.15 & 0.27 & 4.45 & 2.86 \\
\hline 400 & 6.942 & 0.021 & 0.635 & 16.674 & 0.17 & 0.92 & 29.29 & 2.03 & 32.96 & 1.71 \\
\hline 500 & 1.194 & 0.013 & 0.428 & 1.657 & 0.73 & 2.84 & 59.49 & 0.71 & 11.58 & 0.27 \\
\hline 600 & 0.637 & 0.012 & 0.485 & 1.120 & 3.24 & 11.38 & 49.56 & 0.32 & 5.16 & 0.07 \\
\hline 650 & 0.371 & 0.012 & 0.459 & 0.545 & 5.17 & 25.00 & 58.71 & 0.22 & 3.56 & 0.05 \\
\hline 700 & 0.245 & 0.012 & 0.495 & 0.264 & 7.52 & 44.84 & 72.32 & 0.18 & 2.90 & 0.03 \\
\hline 750 & 0.214 & 0.013 & 0.606 & 0.222 & 7.90 & 65.65 & 77.13 & 0.17 & 2.70 & 0.03 \\
\hline 800 & 0.190 & 0.013 & 0.711 & 0.292 & 6.44 & 82.61 & 66.76 & 0.13 & 2.08 & 0.04 \\
\hline 850 & 0.227 & 0.013 & 0.852 & 0.259 & 3.62 & 92.14 & 80.24 & 0.18 & 2.98 & 0.07 \\
\hline 900 & 0.394 & 0.017 & 1.307 & 0.696 & 1.36 & 95.73 & 62.87 & 0.25 & 4.05 & 0.13 \\
\hline 950 & 0.449 & 0.022 & 2.012 & 1.740 & 0.57 & 97.22 & 8.16 & 0.04 & 0.60 & 0.28 \\
\hline 1000 & 2.014 & 0.034 & 2.699 & 1.432 & 0.37 & 98.19 & 86.11 & 1.74 & 28.19 & 0.54 \\
\hline 1050 & 1.212 & 0.072 & 4.378 & 2.574 & 0.31 & 99.01 & 57.47 & 0.70 & 11.39 & 0.72 \\
\hline 1100 & 3.042 & 0.092 & 9.224 & 7.870 & 0.17 & 99.46 & 41.26 & 1.26 & 20.54 & 1.00 \\
\hline 1150 & 7.123 & 0.210 & 13.388 & 20.582 & 0.12 & 99.77 & 25.73 & 1.85 & 29.98 & 1.84 \\
\hline 1200 & 27.096 & 0.153 & 11.153 & 77.315 & 0.06 & 99.92 & 18.10 & 4.94 & 79.04 & 4.32 \\
\hline 1400 & 66.632 & 0.133 & 24.083 & 216.415 & 0.03 & 100.00 & 6.18 & 4.19 & 67.18 & 8.54 \\
\hline
\end{tabular}

${ }^{\mathrm{a}}$ Whole rock is lighter than $2.56 \mathrm{~g} / \mathrm{cm}^{3}$.

the involved plates in response to interactions between the causes mentioned above. Anyway, in this scenario relationships between the cause and effects are still unclear.

\section{Conclusion}

[52] The data set and results presented in this paper reveal that strike-slip brittle deformation within the Kopeh Dagh is transferred southward through the MTZ. This strongly supports the existence of a simple strike-slip faulting mechanism in the northeastern Arabia-Eurasia collision zone, which translate central Iran to the north with respect to Eurasia. In this context the Chakaneh Fault system and Sar'akhor Fault are responsible for at least $2 \mathrm{~mm} / \mathrm{a}$ of the right-lateral strike-slip faulting between the Binalud and Kopeh Dagh mountains. That is to say that $\sim 25 \%$ of the 
northward motion between central Iran and Eurasia in NE Iran is accommodated by the MTZ strike-slip faults. The present-day strike-slip deformation is taken up by reactivated preexisting structures which controlled Cenozoic tectonosedimentary and volcanic evolution of the MTZ. This strike-slip faulting has started at $\sim 5 \mathrm{Ma}$, more probably coeval with the time of the major tectonic reorganization in the Kopeh Dagh [Shabanian et al., 2009]. Comparing preexisting GPS data from Tavakoli [2007], geological and geomorphic mapping within the Kopeh Dagh by Shabanian et al. [2009], and the data and results in this paper, we showed that kinematics of deformation can be described by rigid block faulting in NE Iran. This suggestion is different from the kinematic models proposed during the last 30 years. As a perspective, detailed geomorphic and geological studies are needed to complement the geodynamic puzzle of NE Iran investigating other strike-slip faults between the Kopeh Dagh and Binalud mountain ranges (e.g., the Mashhad Fault).

\section{Appendix A: The ${ }^{40} \mathrm{Ar} /{ }^{39}$ Ar Analytical Procedure and Data}

[53] The minerals (plagioclases) were separated using heavy liquids, a Frantz magnetic separator and finally by hand picking under a binocular microscope to remove all obvious xenocryst from the population with density lighter than 2.56 (see Table A1). The samples were then irradiated at the McMaster reactor, Ontario, in the $5 \mathrm{C}$ position for $28 \mathrm{~h}$ under a $10^{18}$ neutrons $\mathrm{cm}^{-2} \mathrm{~s}^{-1}$ flux. Irradiation interference on $\mathrm{K}, \mathrm{Ca}$, and $\mathrm{Cl}$ were corrected by irradiation of $\mathrm{KCl}$ and $\mathrm{CaF}_{2}$ pure salts. $\mathrm{J}$ factor was estimated by the use of duplicates of the Fish Canyon sanidine standard with an age of $28.02 \pm 0.16 \mathrm{Ma}$ [Renne et al., 1998].

[54] Samples were loaded in aluminum foil packets into a double vacuum Staudacher type furnace, which temperature is calibrated by means of a thermocouple, and step heated in a classical protocol of regularly increasing temperature steps. The gas was purified by the means of cold traps with liquid air and Al-Zr getters during $5 \mathrm{~min}$. Once cleaned, the gas was introduced into a VG3600 mass spectrometer, and one minute was allowed for equilibration before analysis. Sig- nals were measured by mean of a Faraday cup with a resistor of $10^{11} \mathrm{ohm}$ for ${ }^{40} \mathrm{Ar}$ and ${ }^{39} \mathrm{Ar}$, while ${ }^{39} \mathrm{Ar},{ }^{38} \mathrm{Ar}$, ${ }^{37} \mathrm{Ar}$, and ${ }^{36} \mathrm{Ar}$ were analyzed with a photomultiplier after interaction on a Daly plate (Table A1). Gain between both collectors was estimated by duplicate analysis of ${ }^{39} \mathrm{Ar}$ over both during each analysis and also by statistical analysis on a period of several years. This gain is, on average, 54 and is know at better than $1.5 \%$. This error is included in the age calculation. Plateau ages were calculated according to the definition of Fleck et al. [1977], and the given error takes the error on the $\mathrm{J}$ factor into account. Intercept ages are obtained in an inverse isochron diagram of ${ }^{36} \mathrm{Ar} /{ }^{40} \mathrm{Ar}$ versus ${ }^{39} \mathrm{Ar} /{ }^{40} \mathrm{Ar}$ [Roddick et al., 1980], which allows homogeneous excess components to be isolated in many occasions. Errors on age and intercept age include individual errors on each point and linear regression by York's method [York, 1968]. The goodness of fit relative to individual errors is measured by mean square weighted deviation (MSWD) [York, 1968]. If the inverse isochron age is close to the plateau age and ${ }^{40} \mathrm{Ar} /{ }^{36} \mathrm{Ar}$ is not significantly different from present-day ${ }^{40} \mathrm{Ar} /{ }^{36} \mathrm{Ar}$ atmospheric ratio (295.5), we consider that the plateau age is reliable. When this is not the case, we prefer to rely on the inverse isochron age if this one is well determined. Isotopic correlation plots of ${ }^{39} \mathrm{Ar},{ }^{37} \mathrm{Ar}$, and ${ }^{38} \mathrm{Ar}$ are used as proxies for $\mathrm{K} / \mathrm{Ca}\left({ }^{39} \mathrm{Ar} /{ }^{37} \mathrm{Ar}\right)$ and $\mathrm{Cl} / \mathrm{K}$ $\left({ }^{38} \mathrm{Ar} /{ }^{39} \mathrm{Ar}\right)$ ratios.

[55] Acknowledgments. This work was funded by the INSU-CNRS (France) and the International Institute of Earthquake Engineering and Seismology (IIEES, Iran), supervised by D. Hatzfeld and M. G. Ashtiani. We thank M. Mokhtari and M. Zare (IIEES) for support and administrative assistance. Funding was provided by the Dyeti and PNRN programs (INSU-CNRS), and ACI FNS program (French Ministry of Research), within the above mentioned cooperative agreement. SPOT images were provided thanks to the ISIS program (copyright CNES 2004 to 2007, distribution SPOT images S.A.). The samples were analyzed at the argon geochronology laboratory of the Montpellier University, France. E. Shabanian benefits of a Foreign Affair Ministry (Ministère des Affaires Etrangères) grant through French Embassy in Iran and complementary support through the "Cotutelle de thèse" program (ACI du Ministère des Affaires Etrangères). We thank V. Grimault, C. Duhamel, and the staff of the SCAC of the French Embassy in Tehran, for their support. We are grateful to G. Axen, an anonymous reviewer, and an Associate Editor for helpful and constructive reviews. The general governments of Khorassan-e Razavi and Shomali provinces have efficiently helped us over 3 years.

\section{References}

Afshar Harb, A. (1979), The stratigraphy, tectonics and petroleum geology of the Kopet Dagh region, northeastern Iran, Ph.D. thesis, Pet. Geol. Sect., R. Sch. of Mines, Imp. Coll. of Sci. and Technol., London.

Alavi, M. (1992), Thrust tectonics of the Binalood region, NE Iran, Tectonics, 11, 360-370, doi:10.1029/ $91 \mathrm{TC} 02217$.

Allen, M. B., S. Jones, A. Ismail-Zadeh, M. Simmons, and L. Anderson (2002), Onset of subduction as the cause of rapid Pliocene-Quaternary subsidence in the South Caspian Basin, Geology, 30(9), 775-778, doi:10.1130/0091-7613(2002)030<0775: OOSATC $>2.0 . \mathrm{CO} ; 2$.

Allen, M., J. Jackson, and R. Walker (2004), Late Cenozoic reorganization of the Arabia-Eurasia collision and the comparison of short-term and longterm deformation rates, Tectonics, 23, TC2008, doi:10.1029/2003TC001530.
Ambraseys, N., and C. Melville (1982), A History of Persian Earthquakes, Cambridge Univ. Press, Cambridge, U. K.

Amini, B., and N. H. Khan-Nazer (2000), Geological map of Iran, Ser. 7563, Mashkan sheet, scale 1:100 000, Geol. Surv. of Iran, Tehran.

Authemayou, C., D. Chardon, O. Bellier, Z. Malekzadeh, E. Shabanian, and M. R. Abbassi (2006), Late Cenozoic partitioning of oblique plate convergence in the Zagros fold-and-thrust belt (Iran), Tectonics, 25, TC3002, doi:10.1029/2005TC001860.

Authemayou, C., O. Bellier, D. Chardon, L. Benedetti, Z. Malekzade, C. Claude, B. Angeletti, E. Shabanian, and M. R. Abbassi (2009), Quaternary slip-rates of the Kazerun and the main recent faults: Active strikeslip partitioning in the Zagros fold-and-thrust belt, Geophys. J. Int., 178, 524-540, doi:10.1111/j.1365246X.2009.04191.x.
Avouac, J.-P., and P. Tapponnier (1993), Kinematic model of active deformation in central Asia, Geophys. Res. Lett., 20, 895-898, doi:10.1029/ 93GL00128.

Axen, G. J., P. S. Lam, M. Grove, D. F. Stockli, and J. Hassanzadeh (2001), Exhumation of the westcentral Alborz Mountains, Iran, Caspian subsidence, and collision-related tectonics, Geology, 29(6), 559-562, doi:10.1130/0091-7613(2001)029< 0559:EOTWCA $>2.0 . \mathrm{CO} ; 2$.

Bellier, O., and M. L. Zoback (1995), Recent state of stress change in the Walker Lane zone, western Basin and Range province, United States, Tectonics, 14, 564-593, doi:10.1029/94TC00596.

Berberian, M., and R. Yeats (1999), Patterns of historical earthquake rupture in the Iranian Plateau, Bull. Seismol. Soc. Am., 89, 120-139.

Berberian, M., and R. Yeats (2001), Contribution of archaeological data to studies of earthquake history 
in the Iranian Plateau, J. Struct. Geol., 23, 563-584, doi:10.1016/S0191-8141(00)00115-2.

Carey, E. (1979), Recherche des directions principales de contraintes associées au jeu d'une population de failles, Rev, Geol. Dyn. Geogr. Phys., 21, 57-66.

Carey, E., and B. Brunier (1974), Analyse théorique et numérique d'un modèle mécanique élémentaire appliqué à l'étude d'une population de failles, $C . R$. Acad. Sci., Ser. D, 279, 891-894.

Copley, A., and J. Jackson (2006), Active tectonics of the Turkish-Iranian Plateau, Tectonics, 25, TC6006, doi:10.1029/2005TC001906.

England, P., and J. A. Jackson (1989), Active deformation of the continents, Annu. Rev. Earth Planet Sci., 17, 197-226, doi:10.1146/annurev.ea.17. 050189.001213 .

England, P., and D. McKenzie (1982), A thin viscous sheet for continental deformation, Geophys. J. R Astron. Soc., 70, 295-321, doi:10.1111/j.1365246X.1982.tb04969.x.

England, P., and P. Molnar (1997), Active deformation of Asia: From kinematics to dynamics, Science, 278, 647-650, doi:10.1126/science.278.5338.647.

Faccenna, C., O. Bellier, J. Martinod, C. Piromallo, and V. Regard (2006), Slab detachment beneath eastern Anatolia: A possible cause for the formation of the north Anatolian fault, Earth Planet. Sci. Lett., 242, 85-97, doi:10.1016/j.eps1.2005.11.046.

Fleck, R. J., J. F. Sutter, and D. H. Elliot (1977), Interpretation of discordant ${ }^{40} \mathrm{Ar} /{ }^{39} \mathrm{Ar}$ age spectra of Mesozoic tholeiites from Antarctica, Geochim. Cosmochim. Acta, 41, 15-32, doi:10.1016/00167037(77)90184-3.

Flesch, L. M., A. J. Haines, and W. E. Holt (2001), Dynamics of the India-Eurasia collision zone, J. Geophys. Res., 106, 16,435-16,460, doi:10.1029/ 2001JB000208.

Ghaemi, F., F. Ghaemi, and K. Hosseini (1999), Geological map of Iran, Ser. 7766, Neyshabur sheet, scale 1:100 000, Geol. Surv. of Iran, Tehran.

Gordon, R. G., and S. Stein (1992), Global tectonics and space geodesy, Science, 256, 333-342, doi:10.1126/science.256.5055.333.

Hempton, M. R. (1987), Constraints on Arabian plate motion and extensional history of the Red Sea, Tectonics, 6, 687-705, doi:10.1029/TC006i006p00687.

Hollingsworth, J., J. Jackson, R. Walker, M. R. Gheitanchi, and M. J. Bolourchi (2006), Strikeslip faulting, rotation and along-strike elongation in the Kopeh Dagh Mountains, NE Iran, Geophys. $J$. Int., 166, 1161-1177, doi:10.1111/j.1365-246X. 2006.02983.x.

Hollingsworth, J., J. Jackson, J. E. Alarcón, J. J Bommer, and M. J. Bolourchi (2007), The 4th February 1997 Bojnurd (Garmkhan) earthquake in NE Iran: Field, teleseismic, and strong-motion evidence for rupture directivity effects on a strikeslip fault, J. Earthquake Eng., 11, 193-214.

Hollingsworth, J., J. Jackson, R. Walker, and H. Nazari (2008), Extrusion tectonics and subduction in the eastern south Caspian region since $10 \mathrm{Ma}$, Geology, 36(10), 763-766, doi:10.1130/G25008A.1.

Jackson, J., and D. McKenzie (1984), Active tectonics of the Alpine-Himalayan Belt between western Turkey and Pakistan, Geophys. J. R. Astron. Soc., 77(1), 185-264, doi:10.1111/j.1365-246X. 1984.tb01931.x.

Jackson, J. A., A. J. Haines, and W. E. Holt (1995), The accommodation of Arabia-Eurasia plate convergence in Iran, J. Geophys. Res., 100, 15,20515,219, doi:10.1029/95JB01294.

Jackson, J., K. Priestley, M. Allen, and M. Berberian (2002), Active tectonics of the South Caspian Basin, Geophys. J. Int., 148, 214-245, doi:10.1046/ j.1365-246X.2002.01588.x.

Koçyigit, A., A. Yilmaz, S. Adamia, and S. Kuloshvili (2001), Neotectonics of East Anatolian Plateau (Turkey) and Lesser Caucasus: Implication for transition from thrusting to strike-slip faulting, Geodin. Acta, 14(1-3), 177-195, doi:10.1016 S0985-3111(00)01064-0.
Lyberis, N., and G. Manby (1999), Oblique to orthogonal convergence across the Turan block in the postMiocene, AAPG Bull., 83(7), 1135-1160.

Masson, F., M. Anvari, Y. Djamour, A. Walpersdorf, F. Tavakoli, M. Daignières, H. Nankali, an S. Van Gorp (2007), Large-scale velocity field and strain tensor in Iran inferred from GPS measurements: New insight for the present-day deformation pattern within NE Iran, Geophys. J. Int., 170, 436-440, doi:10.1111/j.1365-246X.2007.03477.x.

McClusky, S., R. Reilinger, S. Mahmoud, D. Ben Sari, and A. Tealeb (2003), GPS constraints on Africa (Nubia) and Arabia plate motions, Geophys. $J$. Int., 155(1), 126-138, doi:10.1046/j.1365-246X 2003.02023.x.

McKenzie, D. P. (1972), Active tectonics of the Mediterranean region, Geophys. J. Int., 30(2), 109-185, doi:10.1111/j.1365-246X.1972.tb02351.x.

McKenzie, D., and J. Jackson (1983), The relationship between strain rates, crustal thickening, paleomagnetism, finite strain, and fault movements within a deforming zone, Earth Planet. Sci. Lett., 65, 182 -202, doi:10.1016/0012-821X(83)90198-X.

McKenzie, D., and J. Jackson (1986), A block model of distributed deformation by faulting, J. Geol. Soc., 143, 349-353, doi:10.1144/gsjgs.143.2.0349.

McQuarrie, N., J. M. Stock, C. Verdel, and B. P. Wernicke (2003), Cenozoic evolution of Neotethy and implications for the causes of plate motions, Geophys. Res. Lett., 30(20), 2036, doi:10.1029/ 2003GL017992.

Mercier, J. L., E. Carey-Gailhardis, and M. Sébrier (1991), Paleostress determinations from fault kinematics: Application to the neotectonics of the Himalayan-Tibet and the central Andes, Philos. Trans. R. Soc. London, Ser. A, 337, 41-52, doi:10.1098/rsta.1991.0105.

Molnar, P. (1988), Continental tectonics in the aftermath of plate tectonics, Nature, 335, 131-137, doi: $10.1038 / 335131 \mathrm{a} 0$

Mostriouk, A. O., and V. A. Petrov (1994), Catalogue of focal mechanisms of earthquakes 1964-1990, Materials of World Data Center B, http:/ wwwbrk.adm.yar.ru/russian/1 512/stress/fps cate. htm, 87 pp., World Data Center B, Moscow.

Mount, V. S., and J. Suppe (1987), State of stress near the San Andreas Fault: Implications for wrench tectonics, Geology, 15, 1143-1146, doi:10.1130/ 0091-7613(1987) $15<1143$ :SOSNTS $>2.0 . C O ; 2$

Nyst, M., and W. Thatcher (2004), New constraints on the active tectonic deformation of the Aegean, J. Geophys. Res., 109, B11406, doi:10.1029 2003JB002830.

Peltzer, G., and F. Saucier (1996), Present-day kinematics of Asia derived from geologic fault rates, J. Geophys. Res., 101, 27,943-27,956, doi:10.1029 96JB02698

Regard, V., O. Bellier, J.-C. Thomas, M. R. Abbassi, J. Mercier, E. Shabanian, K. Feghhi, and S Soleymani (2004), The accommodation of ArabiaEurasia convergence in the Zagros-Makran transfe zone, SE Iran: A transition between collision and subduction through a young deforming system, Tec tonics, 23, TC4007, doi:10.1029/2003TC001599.

Regard, V., et al. (2005), Cumulative right-lateral fault slip rate across the Zagros-Makran transfer zone: Role of the Minab-Zendan fault system in accommodating Arabia - Eurasia convergence in southeas Iran, Geophys. J. Int., 162, 177-203, doi:10.1111/ j.1365-246X.2005.02558.x.

Reilinger, R., et al. (2006), GPS constraints on continental deformation in the Africa-Arabia-Eurasia continental collision zone and implications for the dynamics of plate interactions, J. Geophys. Res., 111, B05411, doi:10.1029/2005JB004051.

Renne, P. R., C. C. Swisher, A. L. Deino, D. B. Karner, T. Owens, and D. J. Depaolo (1998), Intercalibration of Standards, absolute ages and uncertainties in ${ }^{40} \mathrm{Ar} /{ }^{39} \mathrm{Ar}$ dating, Chem. Geol., 145, 117-152, doi:10.1016/S0009-2541(97)00159-9.

Replumaz, A., and P. Tapponnier (2003), Reconstruction of the deformed collision zone between India an
Asia by backward motion of lithospheric blocks, J. Geophys. Res., 108(B6), 2285, doi:10.1029/ 2001JB000661.

Roddick, J. C., R. A. Cliff, and D. C. Rex (1980), The evolution of excess argon in alpine biotites, Earth Planet. Sci. Lett., 48, 185-208, doi:10.1016/0012 821X(80)90181-8

Ryerson, F. J., P. Tapponnier, R. C. Finkel, A.-S Mériaux, J. Van der Woerd, C. Lasserre, M.-L. Chevalier, X. Xu, H. Li, and G. C. P. King (2006), Applications of morphochronology to the active tectonics of Tibet, in In Situ-Produced Cosmogenic Nuclides and Quantification of Geological Processes, edited by L. L. Siame, D. L. Bourlès, and E. T. Brown, Spec. Pap. Geol. Soc. Am., 415, 61-86, doi:10.1130/2006.2415(05).

Sahandi, M. R. (1993), Geological quadrangle map of Iran, Map J-4, Sabzevar sheet, scale 1:250 000, Geol. Surv. of Iran, Tehran.

Sella, G. F., T. H. Dixon, and A. Mao (2002), REVEL: A model for recent plate velocities from space Geodesy, J. Geophys. Res., 107(B4), 2081, doi:10.1029/2000JB000033.

Shabanian, E., L. Siame, O. Bellier, L. Benedetti, and M. R. Abbassi (2009), Quaternary slip rates along the northeast boundary of the Arabia-Eurasia collision zone (Kopeh Dagh Mountains, north-east Iran), Geophys. J. Int., 178, 1055-1077, doi:10.1111/j.1365-246X.2009.04183.x.

Siame, L. L., E. Shabanian, and O. Bellier (2009), Extrusion tectonics and subduction in the easter South Caspian region since $10 \mathrm{Ma}$, Comment, Geology, in press.

Stöcklin, J. (1968), Structural history and tectonics of Iran: A review, Am. Assoc. Petrol. Geol. Bull., 52(7), $1229-1258$.

Storti, F., R. E. Holdsworth, and F. Salvini (2003), Intra plate strike-slip deformation belts, in Intra Plate Strike-Slip Deformation Belts, edited by F. Storti et al., Geol. Soc. Spec. Publ., 210, 1-14, doi:10.1144/GSL.SP.2003.210.01.01.

Tavakoli, F. (2007), Present-day kinematics of the Zagros and east of Iran faults, Ph.D. thesis, Univ. of Joseph Fourier, Grenoble, France.

Tchalenko, J. S. (1975), Seismicity and structure of the Kopet Dagh (Iran, USSR), Philos. Trans. R. Soc. London, Ser. A, 278, 1-28, doi:10.1098/rsta.1975.0019.

Thatcher, W. (1995), Microplate versus continuum descriptions of active tectonic deformation, J. Geophys. Res., 100, 3885-3894, doi:10.1029/ 94JB03064.

Thatcher, W. (2003), GPS constraints on the kinematics of continental deformation, Int. Geol. Rev., 45, 191 -212, doi:10.2747/0020-6814.45.3.191.

Thatcher, W. (2007), Microplate model for the presentday deformation of Tibet, J. Geophys. Res., 112, B01401, doi:10.1029/2005JB004244.

Vernant, P., et al. (2004), Present-day crustal deformation and plate kinematics in the Middle East constrained by GPS measurements in Iran and northern Oman, Geophys. J. Int., 157(1), 381-398, doi:10.1111/j.1365-246X.2004.02222.x

Vilotte, J. P., M. Daignieres, and R. Madariaga (1982), Numerical modeling of intraplate deformation: Simple mechanical models of continental collision, J. Geophys. Res., 87, 10,709-10,728, doi:10.1029/ JB087iB13p10709.

Walker, R., and J. Jackson (2004), Active tectonics and Late Cenozoic strain distribution in central and eastern Iran, Tectonics, 23, TC5010, doi:10.1029/ 2003TC001529.

Westaway, R. (1994), Present-day kinematics of the Middle East and eastern Mediterranean, J. Geophys. Res., 99, 12,071-12,090, doi:10.1029/94JB00335.

York, D. (1968), Least-square fitting of a straight line with correlated errors, Earth Planet. Sci. Lett., 5, 320 -324, doi:10.1016/S0012-821X(68)80059-7.

Zamani, B., J. Angelier, and A. Zamani (2008), State of stress induced by plate convergence and stress partitioning in northeastern Iran, as indicated by focal mechanisms of earthquakes, J. Geodyn., 45 , 120 -132, doi:10.1016/j.jog.2007.07.003. 
Zoback, M. D., and J. Townend (2001), Implications of hydrostatic pore pressures and high crustal strength for the deformation of intraplate lithosphere, Tectonophysics, 336, 19-30, doi:10.1016/S00401951(01)00091-9.

Zoback, M. D., et al. (1987), New evidence on the state of stress on the San Andreas fault system, Science,
$238,1105-1111$, doi: $10.1126 /$ science. 238 . 4830.1105 .

M. R. Abbassi, International Institute of Earthquak Engineering and Seismology, BP 19395- 3913 Tehran, Iran. (abbassi@iiiees.ac.ir)

N. Arnaud, Géosciences Montpellier, UMR 5243, Groupe GEODE, CC 060, Université de Montpellier 2, CNRS, Place Eugène Bataillon, F-34095 Montpellie CEDEX 5, France. (nicolas.arnaud@gm.univ-montp2.fr)
O. Bellier, E. Shabanian, and L. Siame, CEREGE, UMR, Université Aix-Marseille, IRD, Collège de France, Europôle de l'Arbois, CNRS, BP 80, F-13545 Aix-en-Provence CEDEX 4, France. (bellier@cerege.fr; ismael@cerege.fr; siame@cerege.fr)

J.-J. Cochemé, Laboratoire de Pétrologie Magmatique, Université Aix-Marseille, Faculté des Sciences de St Jérôme, F-13397 Marseille CEDEX 20, France. (jean-jacques.cocheme@univ-cezanne.fr) 